Louisiana State University

LSU Digital Commons

Faculty Publications

Department of Chemistry

3-3-2017

\title{
Synthesis and Spectroscopic Investigation of a Series of Push- Pull Boron Dipyrromethenes (BODIPYs)
}

\author{
Sunting Xuan \\ Louisiana State University \\ Ning Zhao \\ Louisiana State University \\ Xiangyi Ke \\ University of Houston \\ Zehua Zhou \\ Louisiana State University \\ Frank R. Fronczek \\ Louisiana State University
}

See next page for additional authors

Follow this and additional works at: https://digitalcommons.Isu.edu/chemistry_pubs

\section{Recommended Citation}

Xuan, S., Zhao, N., Ke, X., Zhou, Z., Fronczek, F., Kadish, K., Smith, K., \& Vicente, M. (2017). Synthesis and Spectroscopic Investigation of a Series of Push-Pull Boron Dipyrromethenes (BODIPYs). Journal of Organic Chemistry, 82 (5), 2545-2557. https://doi.org/10.1021/acs.joc.6b02941

This Article is brought to you for free and open access by the Department of Chemistry at LSU Digital Commons. It has been accepted for inclusion in Faculty Publications by an authorized administrator of LSU Digital Commons. For more information, please contact ir@lsu.edu. 


\section{Authors}

Sunting Xuan, Ning Zhao, Xiangyi Ke, Zehua Zhou, Frank R. Fronczek, Karl M. Kadish, Kevin M. Smith, and M. Graça H. Vicente 
Published in final edited form as:

J Org Chem. 2017 March 03; 82(5): 2545-2557. doi:10.1021/acs.joc.6b02941.

\title{
Synthesis and Spectroscopic Investigation of a Series of Push- Pull Boron Dipyrromethenes (BODIPYs)
}

\author{
Sunting Xuan ${ }^{\dagger}$, Ning Zhao ${ }^{\dagger}$, Xiangyi Ke ${ }^{\ddagger}$, Zehua Zhou ${ }^{\dagger}$, Frank R. Fronczek ${ }^{\dagger}, K_{\text {Karl M. }}$ \\ Kadish $^{\ddagger}$, Kevin M. Smith ${ }^{\dagger}$, and M. Graça H. Vicente ${ }^{\dagger,}{ }^{*}$ \\ †Department of Chemistry, Louisiana State University, Baton Rouge, Louisiana 70803, United \\ States \\ ‡Department of Chemistry, University of Houston, Houston, Texas 77204, United States
}

\begin{abstract}
A series of push-pull BODIPYs bearing multiple electron-donating and electron-acceptor groups were synthesized regioselectively from 2,3,5,6,8-pentachloro-BODIPY, and characterized by NMR spectroscopy, HRMS and X-ray crystallography. The influence of the push-pull substituents on the spectroscopic and electrochemical properties of BODIPYs was investigated. Bathochromic shifts were observed for both absorbance (up to $37 \mathrm{~nm}$ ) and emission (up to $60 \mathrm{~nm}$ ) in different solvents upon introduction of the push-pull moieties. DFT calculations, consistent with the spectroscopic and cyclic voltammetry studies, show decreased HOMO-LUMO energy gaps upon the installation of the push-pull moieties. BODIPY 7 bearing thienyl groups on the 2 and 6 positions showed the largest $\lambda_{\max }$ for both absorption (635-653 nm) and emission (706-707 nm), but also the lowest fluorescence quantum yields. All BODIPYs were non-toxic in the dark $\left(\mathrm{IC}_{50}>\right.$ $200 \mu \mathrm{M})$ and showed low phototoxicity $\left(\mathrm{IC}_{50}>100 \mu \mathrm{M}, 1.5 \mathrm{~J} / \mathrm{cm}^{2}\right)$ toward human HEp2 cells.

Despite the relatively low fluorescence quantum yields, the push-pull BODIPYS were effective for cell imaging, readily accumulating within cells and localizing mainly in the ER and Golgi. Our structure-property studies can guide future design of functionalized BODIPYs for various applications, including bioimaging and in dye-sensitized solar cells.
\end{abstract}

\section{Graphical abstract}

\footnotetext{
Corresponding Author: vicente@1su.edu.

Supporting Information

${ }^{1} \mathrm{H},{ }^{13} \mathrm{C}$ and ${ }^{11} \mathrm{~B}$ NMR spectra for all the push-pull BODIPYs, crystal structures with dihedral angles, absorbance and emission spectra, cyclic voltammetry data, DFT calculated frontier orbitals and energy, concentration-dependent dark and phototoxicity, microscopy images. This material is available free of charge via the Internet at http://pubs.acs.org.

Author Contributions

S.X. and N.Z contributed equally to this work

Notes

The authors declare no competing financial interests.
} 


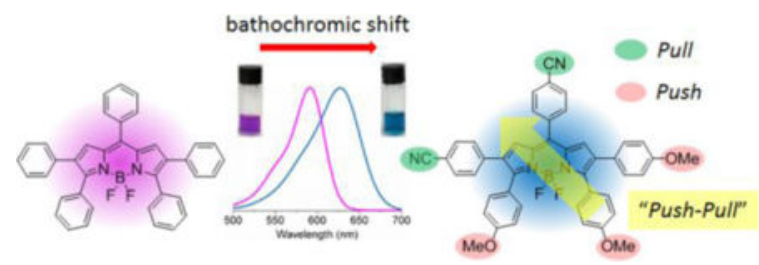

\section{Introduction}

Push-pull chromophores bearing electron-donor (D) and electron-acceptor (A) groups attached to a $\pi$ spacer (D- $\pi-A$ ) have been the subject of research interest due to their wide applications in organic light-emitting devices, ${ }^{1}$ two-photon dyes, ${ }^{2}$ and dye-sensitized solar cells. ${ }^{3}$ Among these, porphyrins and phthalocyanines bearing both $\mathrm{D}$ and $\mathrm{A}$ groups have attracted particular interest in recent decades, as these systems are promising components in dye-sensitized solar cells. ${ }^{3 b, 4}$ Recently, boron dipyrromethenes (BODIPYs) have emerged as $\pi$ spacers of interest, due to their excellent optical and electrochemical properties that enable their application in various fields, including in biological labeling, drug delivery, sensing, bioimaging, theranostics, and in the field of photovoltaics. ${ }^{5}$ BODIPYs are strong UV-Vis absorbing dyes and usually emit sharp fluorescence with high fluorescence quantum yields. BODIPYs are also relatively stable in a physiological environment, and display high thermal and photochemical stabilities. In addition, BODIPYs have high structural tunability, which allows manipulation of their physicochemical properties, such as fluorescence quantum yield, water solubility, and redox potential.

The BODIPY core is itself electron deficient (pull), therefore the installation of electrondonating (push) groups onto the BODIPY core provides a push-pull effect within the molecule. ${ }^{6}$ In recent years, electron-withdrawing groups (pull) have also been introduced onto the BODIPY core to further enhance the pull effect; however, the design, characterization and investigation of BODIPYs bearing both push and pull substituents is so far limited. To date, the push-pull effect has been investigated on three BODIPY platforms of types I, II and III (Figure 1) bearing both electron donor (D) and acceptor (A) moieties. ${ }^{7}$ In addition, the investigation of push-pull effects on aza-BODIPY platforms has been reported. ${ }^{8}$

The attachment of push and pull moieties to the BODIPY platform can have a dramatic effect on the spectroscopic and electrochemical properties of the molecules. ${ }^{9,8 b}$ For example, the presence of an electron-donating group (e.g., 4-aminophenyl) and an electronwithdrawing group (e.g., 4-methoxycarbonylphenyl) on the BODIPY platform can greatly enhance the charge transfer within the molecule, for potential applications in dye-sensitized solar cells,, 10 and two-photon excitation dyes. ${ }^{2 a}, 11$ These push-pull effects can also significantly red-shift the absorption and emission spectra of BODIPYs to the near-infrared region, therefore making them attractive for biological imaging and biosensing applications. ${ }^{8 \mathrm{~b}}$ For example, a $66 \mathrm{~nm}$ bathochromic shift was induced via the introduction of an electron-withdrawing cyano group (-CN) and an electron-donating methoxy group ($\mathrm{OMe}$ ) to the para-positions of the 1,7-phenyl and 3,5-phenyl rings of the corresponding tetraphenyl-aza-BODIPY, respectively. ${ }^{8 b}$ 
The reported DFT electronic structure calculations of a model unsubstituted BODIPY shows large molecular orbital coefficient of the HOMO at the 3,5-positions and large molecular orbital coefficient of the LUMO at the 8-position. ${ }^{12}$ Therefore, the introduction of electrondonating group(s) at the 3,5-positions and electron-withdrawing group at the 8-position of BODIPYs, as shown in platform II, is expected to have the largest impact on both the spectroscopic and electrochemical properties of this type of dye, by changing the characteristics of the HOMO and LUMO (e.g., lower the energy gaps between HOMO and LUMO).

Herein, we report the design and synthesis of three new push-pull BODIPY platforms (Figure 1, platforms IV, V, VI) bearing multiple push-pull moieties, consisting of 2-4 electron-donor groups and 1-2 electron acceptor(s). The seven new BODIPYs were prepared regioselectively from the same precursor, 2,3,5,6,8-pentachloro-BODIPY (1), using $\operatorname{Pd}(0)$-catalyzed Stille and Suzuki cross-coupling reactions with commercially available reagents. All platforms feature an electron-withdrawing group at the 8-position and electrondonating groups at the 3 and 5 positions. In addition, since the introduction of electron-rich thienyl groups, particularly at the 2 and 6 positions, induces large bathochromic and Stokes' shifts on BODIPYs, ${ }^{13}$ two thienyl donors were also installed at the 2 and 6 positions, to give platform V (Figure 1). In order to further investigate the effects of push-pull groups at the 2,6-positions on the spectroscopic and electrochemical properties of BODIPYs, an additional set of push-pull moieties was regioselectively introduced at the 2 and 6 positions to give platform VI (Figure 1). Cyclic voltammetry and DFT calculations were conducted on all the BODIPYs, and a systematic comparison of these platforms with two model BODIPYs (3,5,8-triphenyl- and 2,3,5,6,8-pentaphenyl-BODIPY) was performed to evaluate the influence of the push-pull effect on their spectroscopic and electrochemical properties.

\section{Results and Discussion}

\section{Synthesis}

BODIPYs $2,3,4,6 \mathbf{a}, \mathbf{6 b}, 7$, and $\mathbf{8}$ were synthesized by Suzuki or Stille cross-coupling reactions from the same precursor in moderate to good yields, as shown in Schemes 1 and 2. The starting 2,3,5,6,8-pentachloro-BODIPY 1 was prepared from 8-chloro-BODIPY, as previously reported. ${ }^{13 \mathrm{a}}$ Based on the known regioselectivity of the pentachloro-BODIPY (reactivity order: $8-\mathrm{Cl}>3,5-\mathrm{Cl}>2,6-\mathrm{Cl}$ ), ${ }^{13 a}$ different functional groups can be introduced at the BODIPY periphery allowing for the design of various push-pull BODIPYs through versatile $\operatorname{Pd}(0)$-catalyzed cross-coupling reactions. Furthermore, the unsubstituted 1,7positions of BODIPY 1 are expected to favor relatively small dihedral angles between the substituents and the BODIPY core, potentially leading to increased electronic interactions. In this study, 2-(tributylstannyl)thiophene and/or 4-methoxyphenyl boronic acid were chosen as the electron-donating sources, and 4-benzyloxycarbonylphenyl or 4-cyanophenyl boronic acid were chosen as the electron-withdrawing species to confer the BODIPYs push-pull characteristics. Two electron donor groups were introduced at the 3,5-positions (largest molecular orbital coefficient of the HOMO) and one electron acceptor group was introduced at the 8-position (largest molecular orbital coefficient of the LUMO) of all BODIPY platforms, e.g. platform IV; in addition, two electron donors (platform V) or one donor and 
one acceptor (platform VI) were introduced at the 2,6-positions. The 4-

benzyloxycarbonylphenyl boronic acid, prepared by adapting a reported procedure, ${ }^{14}$ has the additional advantage of providing functionalization for subsequent conjugation with biomolecules upon debenzylation. BODIPYs $\mathbf{2}$ and $\mathbf{4}$ bearing unsubstituted phenyl groups, were also synthesized as model compounds for comparison purposes, using tributylphenylstannane and $3 \mathrm{~mol} \%$ of $\mathrm{Pd}\left(\mathrm{PPh}_{3}\right)_{4}$ or $\mathrm{Pd}\left(\mathrm{PCy}_{3}\right) \mathrm{G} 2$ in refluxing toluene, ${ }^{34}$ giving yields of $61 \%$ and $41 \%$, respectively (Scheme 1 ).

The reaction of 2,3,5,6,8-pentachloro-BODIPY 1 with 2.5 equiv. of 4benzyloxycarbonylphenyl or with 10 equiv. of 4-cyanophenyl boronic acid, in the presence of $3 \mathrm{~mol} \%$ of $\mathrm{Pd}\left(\mathrm{PPh}_{3}\right)_{4}$ and $1 \mathrm{M} \mathrm{Na}_{2} \mathrm{CO}_{3}$ (aq) in refluxing toluene, regioselectively produced BODIPYs $\mathbf{5 a}$ and $\mathbf{5 b}$ in $70 \%$ and $50 \%$ yields, respectively. Subsequently, BODIPYs $\mathbf{5 a}$ and $\mathbf{5 b}$ were treated with 3 equiv. of 4-methoxyphenyl boronic acid under similar conditions to regioselectively produce $\mathbf{6 a}$ and $\mathbf{6 b}$ (platform IV) in $60 \%$ and $66 \%$ yields, respectively (Scheme 1). BODIPYs 7 (platform V) and $\mathbf{8}$ (platform VI) were prepared from $\mathbf{6 b}$, using a single Stille reaction, or a two-step Suzuki cross-coupling reaction, in 55\% and 54\% overall yields, respectively (Scheme 2). Compared with the $\mathrm{Pd}\left(\mathrm{PPh}_{3}\right)_{4}$ catalyst, $\mathrm{Pd}\left(\mathrm{PCy}_{3}\right) \mathrm{G} 2$ greatly increased the yield of the cross-coupling reactions at the 2,6-positions, due to the more reactive complex formed by the bulkier ligands of the $\mathrm{Pd}\left(\mathrm{PCy}_{3}\right) \mathrm{G} 2$ catalyst. ${ }^{13 \mathrm{a}, 15}$ For comparison purposes, BODIPY $\mathbf{3}$ was also prepared from $\mathbf{2}$ using 2-(tributylstannyl)thiophene and $\mathrm{Pd}\left(\mathrm{PCy}_{3}\right) \mathrm{G} 2$ in refluxing toluene, in $62 \%$ yield. The structures of the new BODIPYs were confirmed by ${ }^{1} \mathrm{H},{ }^{13} \mathrm{C}$, and ${ }^{11} \mathrm{~B}$ NMR spectroscopy, and by HRMS (see Supporting Information, Figures S1-27).

\section{X-ray crystallography}

The X-ray crystal structures for BODIPYs $2,4,5 \mathbf{a}, \mathbf{6 a}, \mathbf{6 b}, \mathbf{7}$ and 8 were obtained and are shown in Figure 2. In these structures, the dihedral angles between the 8-aryl substituent and the 12-atom BODIPY core were found to be $62.0,59.4,49.7,56.6,63.7,54.1$, and $60.7^{\circ}$ for $\mathbf{2}, \mathbf{4}, \mathbf{5 a}, \mathbf{6 a}, \mathbf{6 b}, \mathbf{7}$ and $\mathbf{8}$, respectively (Figure S28). In the absence of 1,7-substituents, the dihedral angles are significantly smaller (by about $30^{\circ}$ ) compared with 1,7-substituted BODIPYs (for example in 1,7-dimethyl-BODIPYs) in which the 8-substituent is almost perpendicular with the BODIPY core. ${ }^{13 c}, 16$ This decrease in dihedral angle could lead to better conjugation and electronic communication between the 8-aryl substituent and the BODIPY core, therefore enhancing the push-pull effect. The dihedral angles between the 3,5-aryl substituents and the BODIPY core are also in the range of $45-65^{\circ}$ for all the compounds, except for BODIPY 7, which shows dihedral angles of 70.3 and $86.1^{\circ}$ (Figure S32), due to the presence of the 2,6-thienyl groups. On the other hand, the dihedral angles between the 2,6-substituents in BODIPYs 4, 7 and $\mathbf{8}$ and the 12-atom core are somewhat smaller, in the range of $6-44^{\circ}$, particularly for BODIPY 7 with thiophene groups on the 2,6positions (dihedral angles 6.0 and $27.5^{\circ}$, Figure S29-31). These results suggest that the push-pull moieties on the 2,6-positions as in the case of platform VI could lead to enhanced electronic interactions.

In compounds 4,7 , and 8 bearing 2,6-substituents, the $\mathrm{C}_{9} \mathrm{~N}_{2} \mathrm{~B}$ BODIPY cores are fairly planar, with mean deviations from coplanarity of $0.040,0.035$, and $0.053 \AA$, respectively. In 
the compounds having chlorine at the 2,6-positions, the cores are less planar, the central sixmembered $\mathrm{C}_{3} \mathrm{~N}_{2} \mathrm{~B}$ ring having a slight envelope conformation with boron at the flap position. The B atom lies $0.17,0.14,0.15$ (mean of two), and $0.23 \AA$ out of the plane of the other five atoms for $\mathbf{2}, \mathbf{5 a}, \mathbf{6 a}$, and $\mathbf{6 b}$, respectively. The $\mathrm{C}-\mathrm{Cl}$ bond distances in these BODIPYs are in the 1.681(2) - 1.758(8) ̊̊ range.

\section{Spectroscopic properties}

The spectroscopic properties of the push-pull BODIPYs were evaluated in three solvents, in increasing order of polarity: toluene, THF and acetonitrile, and the results are summarized in Table 1 and in Figures 3-5 (see also Figures S33-S39 in the Supporting Information). All compounds show strong $\mathrm{S}_{0}-\mathrm{S}_{1}$ transitions with molar absorption coefficients in the range $23,000-72000 \mathrm{M}^{-1} \mathrm{~cm}^{-1}$. Weaker and broader absorption bands centered at around $400 \mathrm{~nm}$ were observed at higher energy, which are attributed to $S_{0}-S_{n}(n \geq 2)$ transitions of the BODIPY moiety. ${ }^{6 c,}$, $a, 12$ In addition, $\pi-\pi *$ transitions at $230-320 \mathrm{~nm}$ were also observed for all BODIPYs. ${ }^{9 \mathrm{a}}$ In comparison with the model 3,5,8-triphenyl-BODIPY 2, compounds 6a and $\mathbf{6 b}$ bearing electron-donor (-OMe) groups at the para-position of the 3,5-phenyls and an electron-acceptor group $\left(-\mathrm{CO}_{2} \mathrm{Bn}\right.$ or $\left.-\mathrm{CN}\right)$ at the para-position of the 8-phenyl group exhibited $25-37 \mathrm{~nm}$ and $40-48 \mathrm{~nm}$ bathochromic shifts in the absorption and emission bands, respectively (Figure 3). An enhanced pull effect in the case of BODIPY $\mathbf{6 b}$ was observed, as this compound displays larger red-shifts for both the absorbance and emission bands compared with 6a. Since the CN group (Hammett parameter $\sigma_{p}=0.66$ ) ${ }^{17}$ is more electron-withdrawing than the $\mathrm{CO}_{2} \mathrm{Bn}$ group (Hammett parameter $\sigma_{\mathrm{p}}=0.56$ ),${ }^{17}$ these parameters are helpful in predicting push-pull effects in BODIPY systems. The introduction of phenyl groups at the 2,6-positions, as in BODIPY 4, further induced bathochromic shifts of 18-20 nm for absorption and 19-28 nm for emission relative to 2; larger red-shifts were observed upon introduction of electron-donating thienyl groups at the 2,6-positions, in the order of $54-56 \mathrm{~nm}$ for absorption and $77-95 \mathrm{~nm}$ for emission, as previously observed. ${ }^{13 \mathrm{a},} 18$

In all solvents, push-pull BODIPY 7, bearing two thienyl groups at the 2 and 6 positions, shows the longest $\lambda_{\max }$ for absorption (635-653 nm) and emission (706-707 nm), and the largest Stokes shift (54-71 nm) of all BODIPYs in the three solvents. These results are consistent with previous studies showing that the thienyl groups, especially at the 2,6positions, induce large bathochromic shifts in the absorption and emission bands, and enhanced Stokes shifts on BODIPYs. ${ }^{13 a}$, $13 c, 16$ The larger Stokes shifts are presumably due to the geometry difference between the $S_{0}$ and $S_{1}$ states upon excitation, resulting in increased geometry relaxation. ${ }^{16,21}$ In comparison with $\mathbf{3}$, BODIPY 7 shows bathochromic shifts of 22-25 nm for absorption and 23-27 nm for emission, induced by the electron-donor 3,5-p-methoxyphenyl groups and the electron-acceptor 8-p-cyanophenyl group (Figure 4). On the other hand, the introduction of additional electron-donor and acceptor moieties, as in BODIPY 8, induced greater bathochromic shifts, in the order of 30-34 nm for absorption and 55-60 nm for emission, in comparison with 4 (Figure 5). These results show that the number and electronic nature of substituents on the BODIPY platform induce bathochromic shifts of different extent, and are complemented by the electrochemistry and DFT studies discussed below. 
As the polarity of the solvent increases from toluene $\left(E_{\mathrm{T}}{ }^{\mathrm{N}}=0.099\right)$ to $\operatorname{THF}\left(E_{\mathrm{T}}{ }^{\mathrm{N}}=0.207\right)$ and to acetonitrile $\left(E_{\mathrm{T}}{ }^{\mathrm{N}}=0.460\right),{ }^{19}$ the observed $\lambda_{\max }$ generally decreased for both absorption $(6-22 \mathrm{~nm})$ and emission $(0-15 \mathrm{~nm})$, along with a gradual decrease in the relative fluorescence quantum yields. The decrease in $\lambda_{\max }$ is probably due to a decrease in the dipole moment of the BODIPY upon excitation, associated with the intramolecular charge transfer (ICT) between the donor and acceptor $\left(\mu_{\mathrm{g}}>\mu_{\mathrm{e}}\right.$, where $\mu_{\mathrm{g}}$ and $\mu_{\mathrm{e}}$ are the ground and excited state dipole moments), indicating that the ground state is better stabilized by the polar solvents. ${ }^{19,} 22$ The decreased quantum yield with increase solvent polarity is consistent with previous observations, and is attributed to the increase of nonradiative decay in more polar solvents. ${ }^{8 b}$, 9a, 9c, 9d, 23 A 2-4 fold decrease in fluorescence quantum yields was observed by comparing BODIPYs 2 to $6 \mathbf{a}$ and $6 \mathbf{b}, 3$ to 7 , and $\mathbf{4}$ to 8 , which can be attributed to the ICT between donors and acceptors ${ }^{9 b}, 10$ and the internal conversion between narrower band gaps. ${ }^{24}$ ICT is known to influence the rate of nonradiative relaxation of fluorophores, resulting in decreased fluorescence quantum yields. ${ }^{25}$ Another possible reason for the low fluorescence quantum yields observed for BODIPYs $\mathbf{3}$ and $\mathbf{7}$ is the greater freedom of rotation of the small thienyl groups in comparison with phenyl, which increases the energy lost to nonradiative decay. ${ }^{16}$ Interestingly, the quantum yield for BODIPY 8 decreased dramatically, 11-48 fold in the different solvents compared with BODIPY 4, which could be due to enhanced ICT resulting from the multiple sets of push-pull moieties in this compound. On the other hand, the Stokes shift increased for all the compounds as the polarity of the solvent increased. Among the different BODIPYs, the Stokes shift for $\mathbf{8}$ increased the most $(19 \mathrm{~nm})$ upon going from toluene to acetonitrile, indicating a large difference in dipole moment between the ground and excited states. ${ }^{9 a,} 23$

\section{Electrochemistry}

The electrochemistry of the seven push-pull BODIPYs was investigated in three different solvents, THF, $\mathrm{PhCN}$ and $\mathrm{CH}_{3} \mathrm{CN}$, with similar results being obtained in all cases. Each BODIPY undergoes two one-electron reductions and two one-electron oxidations, with the exact potential depending upon the type and location of the electron donor and/or electron acceptor group on the molecule. A summary of the measured potentials in $\mathrm{PhCN}, 0.1 \mathrm{M}$ TBAP is given in Table 2 (the potential data in $\mathrm{CH}_{3} \mathrm{CN}$ and THF are given in Table $\mathrm{S} 1$ of the Supporting Information) and examples of cyclic voltammograms are shown in Figure 6 which are arranged according to the HOMO-LUMO gap that varied in magnitude between $2.16 \mathrm{~V}$ in the case of BODIPY 2 and $1.79 \mathrm{~V}$ in case of BODIPY 7. The HOMO-LUMO gap obtained by cyclic voltammetry decreased after introduction of the push and pull groups into the BODIPY platforms, from $\mathbf{2}$ to $\mathbf{6 a}$ and $\mathbf{6 b}$, from $\mathbf{3}$ to $\mathbf{7}$, and from $\mathbf{4}$ to $\mathbf{8}$, consistent with the trend of the corresponding maximum absorption and emission wavelengths obtained in the spectroscopic studies (Table 1, Figures 3-5). All BODIPYs were characterized by welldefined redox reactions and an overall mechanism is shown in Scheme 3.

The first one-electron reductions of the push-pull BODIPYs are facile and generate a $\pi$ anion radical at $E_{1 / 2}$ values of -0.53 to $-0.58 \mathrm{~V}$ in the case of compounds $2,6 \mathbf{a}$ and $\mathbf{6 b}$, -0.64 or $-0.68 \mathrm{~V}$ in the case of compounds 7 and $\mathbf{8}$, and -0.72 or $-0.77 \mathrm{~V}$ in the case of compounds 3 and 4 . All of these reductions are substantially easier (occur at more positive potentials) than for reduction of previously synthesized BODIPYs lacking the current set of 
push-pull substituents. ${ }^{26} \mathrm{~A}$ second one-electron addition is also seen for these BODIPYs. This reduction is assigned to the formation of a BODIPY dianion and occurs at a potential which is located 1.04 or $0.74 \mathrm{~V}$ more negative than $E_{1 / 2}$ for the first reduction, as shown in Figure 6 . The second one-electron addition is followed by a rapid chemical reaction for five of the seven investigated BODIPYs but it is reversible and well-defined for $\mathbf{6 a}$ and $\mathbf{6 b}$. To the best of our knowledge, these two compounds are the only monomeric BODIPYs reported to undergo two reversible one-electron reductions. ${ }^{26-27}$ The first one-electron oxidation is also reversible for five of the seven investigated BODIPYs, the only exceptions being for compounds $\mathbf{3}$ and $\mathbf{7}$ where a rapid chemical reaction followed electron transfer. The initial electrooxidation is assigned as generating a BODIPY $\pi$-cation radical and this process is followed by a second irreversible oxidation at more positive potentials, as shown in Figure 6. The nature of the chemical reactions coupled to the electron transfer was not investigated in the current study but are probably associated with radical coupling and dimer formation as previously reported for other BODIPYs. ${ }^{26}$

\section{DFT Calculations}

To provide further insight into the spectroscopic and electrochemical properties of the pushpull BODIPYs, DFT calculations were conducted and the results are summarized in Figure 7, and Table S2/Figure S40 of the Supporting Information. With the installation of the electron-donating (-OMe) and electron-withdrawing $\left(-\mathrm{CN}\right.$ and $\left.-\mathrm{CO}_{2} \mathrm{Bn}\right)$ groups to, respectively, the 3,5- and 8-para-phenyl positions, the molecular orbital coefficient on the HOMO is shifted to the substituents bearing the electron-donating groups, whereas the molecular orbital coefficient on the LUMO is shifted to the 8-position bearing the electronwithdrawing group (Figures 7 and S40). As a result, the overall HOMO-LUMO gap decreases by approximately $0.2 \mathrm{eV}$ after the introduction of the push-pull moieties, from 2 to 6a and $6 \mathrm{~b}$, from $\mathbf{3}$ to $\mathbf{7}$, and from $\mathbf{4}$ to $\mathbf{8}$ (Table S2, Figure 7). This trend in the HOMOLUMO gap $(2>6 \mathbf{a}$ and $6 \mathrm{~b}, 3>\mathbf{7}, \mathbf{4}>\mathbf{8})$ is consistent with the results obtained from cyclic voltammetry (Table 2) and from the spectroscopic studies (Table 1).

\section{Studies in human HEp2 cells}

The concentration-dependent dark and phototoxicity $\left(1.5 \mathrm{~J} / \mathrm{cm}^{2}\right.$ light dose), and the timedependent cellular uptake of BODIPYs $\mathbf{2}, \mathbf{3}, \mathbf{4}, \mathbf{6 a}, \mathbf{6 b}, \mathbf{7}$ and $\mathbf{8}$ were evaluated in HEp2 cells, and the results are summarized in Table 3, Figures 8-10 and S41-42 of the Supporting Information. None of the BODIPYs were found to be cytotoxic in the dark up to $200 \mu \mathrm{M}$ concentration, nor upon light irradiation $\left(1.5 \mathrm{~J} / \mathrm{cm}^{2}\right)$ up to $100 \mu \mathrm{M}$ concentration. BODIPY 4 was the only compound that showed slight phototoxicity (Figure S42 of the Supporting Information), but still with $\mathrm{IC}_{50}$ above $100 \mu \mathrm{M}$. These results are in agreement of previous reports on the low cytotoxicity of BODIPYs, in part due to their usually low quantum yields for triplet state formation. ${ }^{28}$

The cellular uptake of all BODIPYs generally increased with time as shown in Figure 8. Among the BODIPYs, $\mathbf{2}$ and $\mathbf{8}$ were taken-up faster and more efficiently at all times investigated, particularly in the first 4 hours, after which a slower uptake was observed and, in the case of 8 , a plateau was reached after 8 hours. BODIPY $3,4,6 \mathbf{a}$, and 7 exhibited very low uptake in HEp2 cells, which could be due to their high hydrophobicity and poor water 
solubility. The higher cellular uptake observed for $\mathbf{6 b}$ and $\mathbf{8}$ compared with the other compounds could be due to the introduction of the polar-OMe and $-\mathrm{CN}$ groups which enhances their polarity and water solubility. It is interesting to note that the dichlorotriphenyl-BODIPY 2 accumulated the most within cells after 24 hours, whereas the least polar and most hydrophobic pentaphenyl-BODIPY 4 accumulated the least.

Fluorescence microscopy was conducted using HEp2 cells to investigate the main subcellular localization sites of the BODIPYs. The organelle-specific probes used in the overlay experiments are LysoSensor Green (lysosomes), MitoTracker Green (mitochondria), ER Tracker Blue/White (endoplasmic reticulum) and BODIPY Ceramide (Golgi). The results are shown in Figures 9 and 10 for push-pull BODIPYs $\mathbf{6 b}$ and $\mathbf{8}$ that accumulated most efficiently within cells, and in Figures S43-45 of the Supporting Information for 2, 3, 4, 6a and 7. All BODIPYs were observed in multiple organelles (see Table S3 of the Supporting Information), the major localization sites are the cell ER, lysosomes, mitochondria, and the Golgi apparatus, in agreement with previously reported studies. ${ }^{28 \mathrm{a}}$, $28 \mathrm{~b}$

\section{Conclusions}

A series of push-pull BODIPYs were synthesized in good yields from a single 2,3,5,6,8pentachloro-BODIPY (1), via regioselective Suzuki and Stille cross-coupling reactions. The structures of all the compounds were confirmed by HRMS, NMR spectroscopy, and X-ray crystallography. A systematic study was performed before and after installation of electronwithdrawing (at the 8-position and, in one case also at the 2-position), and electron-donating (at the 3,5-, 2,3,5- and 2,3,5,6-positions) groups, to investigate the influence of the push-pull effect on their spectroscopic and electrochemical properties. Bathochromic shifts were observed in both absorbance (up to $37 \mathrm{~nm}$ ) and emission (up to $60 \mathrm{~nm}$ ) in solvents with different polarities after the installation of electron-donor and acceptor groups. DFT calculations indicate that the HOMO-LUMO energy gap decreases with the installation of the push-pull moieties. The trend of the DFT calculated HOMO-LUMO energy was found to be: (1) $\mathbf{2}>\mathbf{6 a}$ and $\mathbf{6 b}$; (2) $\mathbf{3}>\mathbf{7}$; (3) $\mathbf{4}>\mathbf{8}$, which is consistent with the HOMO-LUMO trend observed experimentally from cyclic voltammetry. BODIPY $\mathbf{4}$ bearing thienyl groups at the 2 and 6 positions exhibits the longest $\lambda_{\max }$ for absorption (635-653 $\mathrm{nm}$ ) and emission (706$707 \mathrm{~nm})$ and the largest Stokes shift $(54-71 \mathrm{~nm})$ in all solvents investigated. On the other hand, the fluorescence quantum yield decreased up to 48 -fold after the introduction of the push-pull moieties, probably due to ICT between donor and acceptor, and nonradiative decay. All BODIPYs showed well-defined redox reactions, and no dark cytoxicity ( $\mathrm{IC}_{50}>$ $200 \mu \mathrm{M})$ nor phototoxicity $\left(\mathrm{IC}_{50}>100 \mu \mathrm{M}, 1.5 \mathrm{~J} / \mathrm{cm}^{2}\right)$ in human HEp2 cells. Among the push-pull BODIPYs, compounds $\mathbf{6 b}$ and $\mathbf{8}$ showed the highest cellular uptake. Despite the relatively low fluorescence quantum yields, the push-pull BODIPYs were efficient in in cell imaging investigations, and localized in multiple cell organelles, including the ER, Golgi, lysosomes, and mitochondria. 


\section{Experimental Section}

\section{Synthesis}

All commercial available reagents and solvents were used as received. Reactions were monitored by analytical TLC (precoated, polyester backed, $60 \AA, 0.2 \mathrm{~mm}$ ). Purifications by column chromatography used silica gel (230-400 mesh, $60 \AA$ ), and preparative TLC plates. ${ }^{1} \mathrm{H}$ and ${ }^{13} \mathrm{C}$ NMR spectra were obtained on the NMR spectrometers $(400 \mathrm{MHz}$ or 500 $\mathrm{MHz}$ for ${ }^{1} \mathrm{H}$ NMR and $100 \mathrm{MHz}$ or $125 \mathrm{MHz}$ for ${ }^{13} \mathrm{C} \mathrm{NMR}$ ) at $300 \mathrm{~K} .{ }^{11} \mathrm{~B}$ NMR spectra were obtained on a NMR spectrometer with $128 \mathrm{MHz}$, using $\mathrm{BF}_{3} \cdot \mathrm{OEt}_{2}$ as external reference. Chemical shifts $(\delta)$ are given in parts per million $(\mathrm{ppm})$ in $\mathrm{CDCl}_{3}(7.27 \mathrm{ppm}$ for ${ }^{1} \mathrm{H}$ NMR, $77.0 \mathrm{ppm}$ for ${ }^{13} \mathrm{C}$ NMR) and coupling constants $(J)$ are given in $\mathrm{Hz}$. All high resolution mass spectra (HRMS) were obtained on a ESI-TOF mass spectrometer. Melting points were measured using a capillary melting point apparatus equipped with a thermometer. Crystal structures were determined using data collected at low temperature (90K) on a diffractometer equipped with a focusing monochromator for the Mo X-ray beam, a $\mathrm{Cu}$ microfocus $\mathrm{X}$-ray source, and an chiller.

\subsection{General procedure for Suzuki cross-coupling reactions-The starting} BODIPY was added to a $15 \mathrm{~mL}$ round-bottomed flask followed by the addition of either 3 mol\% of $\mathrm{Pd}\left(\mathrm{PPh}_{3}\right)_{4}$ (for 5a, 5b) or $\mathrm{Pd}\left(\mathrm{PCy}_{3}\right) \mathrm{G} 2$ (for $\mathbf{6 a}, \mathbf{6 b}$ and $\mathbf{8}$ ). The flask was evacuated and refilled with nitrogen three times, before toluene $(4 \mathrm{~mL})$ and $1 \mathrm{M} \mathrm{Na}_{2} \mathrm{CO}_{3}(\mathrm{aq})(1 \mathrm{~mL})$ were added to the mixture. Boronic acids were added portion-wise, and the reaction mixture was stirred and heated under nitrogen at $90-100{ }^{\circ} \mathrm{C}$. The reaction was monitored by analytical TLC every $30-60 \mathrm{~min}$. Water $(20 \mathrm{~mL})$ was added to the reaction mixture, and dichloromethane $(10 \mathrm{~mL} \times 3)$ was used for extraction of the organic components. The organic layers were combined, washed with aqueous saturated brine, then water, and dried over anhydrous $\mathrm{Na}_{2} \mathrm{SO}_{4}$. The solvent was removed under vacuum, and the resulting residue was purified by column chromatography using dichloromethane/hexanes or ethyl acetate/ hexanes as the elution solvents.

\subsubsection{2,3,5,6,8-Pentachloro-BODIPY (1) was prepared as previously} reported. ${ }^{13 a}$ : $2,3,5,6,8$-Pentachloro-BODIPY (1) was prepared as previously reported. ${ }^{13 a}$

1.1.2. 8-(4-Benzyloxycarbonylphenyl)-2,3,5,6-tetrachloro-BODIPY (5a): This BODIPY was prepared from $1(20.0 \mathrm{mg}, 0.055 \mathrm{mmol})$ and $2.5 \mathrm{eq}$ of 4-benzyloxycarbonylphenyl boronic acid (35.2 mg, $0.14 \mathrm{mmol})$, yielding $20.8 \mathrm{mg}, 70 \%$ of BODIPY 5a as a red solid: $\mathrm{mp} 186-188{ }^{\circ} \mathrm{C} ;{ }^{1} \mathrm{H} \mathrm{NMR}\left(\mathrm{CDCl}_{3}, 400 \mathrm{MHz}\right) \delta(\mathrm{ppm})=8.26-8.28(\mathrm{~m}, 2 \mathrm{H}), 7,57-7.59(\mathrm{~m}$, $2 \mathrm{H}), 7.42-7.51(\mathrm{~m}, 5 \mathrm{H}), 6.79(\mathrm{~s}, 2 \mathrm{H}), 5.45(\mathrm{~s}, 2 \mathrm{H}) ;{ }^{13} \mathrm{C} \mathrm{NMR}\left(\mathrm{CDCl}_{3}, 125 \mathrm{MHz}\right) \delta(\mathrm{ppm})=$ 166.2, 143.9, 142.2, 135.8, 235.5, 132.9, 131.2, 130.3, 130.1, 128.7, 128.6, 128.3, 127.9, 122.3, 67.4; ${ }^{11} \mathrm{~B} \mathrm{NMR}\left(\mathrm{CDCl}_{3}, 128 \mathrm{MHz}\right) \delta(\mathrm{ppm})=-0.24-0.18\left(\mathrm{t}, J_{(\mathrm{B}, \mathrm{F})}=26.4 \mathrm{~Hz}\right)$; HRMS (ESI-TOF): $\mathrm{m} / \mathrm{z}$ calculated for $\mathrm{C}_{23} \mathrm{H}_{13} \mathrm{BCl}_{4} \mathrm{~F}_{2} \mathrm{~N}_{2} \mathrm{O}_{2}$ : 536.9834; found: 536.9809 $\left[\mathrm{M}^{-}\right]$.

1.1.3. 8-(4-Cyanophenyl)-2,3,5,6-tetrachloro-BODIPY (5b): This BODIPY was prepared from (1) (11.4 mg, $0.031 \mathrm{mmol})$ and 10 eq of 4-cyanophenyl boronic acid (46.0 mg, 0.32 
mmol), yielding $6.7 \mathrm{mg}, 50 \%$ of BODIPY $\mathbf{5 b}$ as red solid: $\mathrm{mp} 280-282{ }^{\circ} \mathrm{C} ;{ }^{1} \mathrm{H}$ NMR $\left(\mathrm{CDCl}_{3}, 400 \mathrm{MHz}\right) \delta(\mathrm{ppm})=7.89-7.90(\mathrm{~m}, 2 \mathrm{H}), 7.62-7.64(\mathrm{~m}, 2 \mathrm{H}), 6.76(\mathrm{~s}, 2 \mathrm{H}) ;{ }^{13} \mathrm{C}$ $\operatorname{NMR}\left(\mathrm{CDCl}_{3}, 125 \mathrm{MHz}\right) \delta(\mathrm{ppm})=144.6,140.6,135.9,132.6,131.0,130.8,127.6,122.7$, $117.4,115.3 ;{ }^{11} \mathrm{~B} \mathrm{NMR}\left(\mathrm{CDCl}_{3}, 128 \mathrm{MHz}\right) \delta(\mathrm{ppm})=-0.26-0.15\left(\mathrm{t}, J_{(\mathrm{B}, \mathrm{F})}=26.7 \mathrm{~Hz}\right)$; HRMS (ESI-TOF): $\mathrm{m} / \mathrm{z}$ calcd for $\mathrm{C}_{16} \mathrm{H}_{6} \mathrm{BCl}_{4} \mathrm{~F}_{2} \mathrm{~N}_{3}$ : 427.9419; found: 427.9412 [ $\mathrm{M}^{-}$].

1.1.4. 8-(4-Benzyloxycarbonylphenyl)-3,5-di(4-methoxyphenyl)-2,6-dichloro-BODIPY (6a): This BODIPY was prepared from $(\mathbf{5 a})(12.9 \mathrm{mg}, 0.024 \mathrm{mmol})$ and $10 \mathrm{eq}$ of $4-$ methoxyphenyl boronic acid ( $10.9 \mathrm{mg}, 0.072 \mathrm{mmol})$, yielding $9.8 \mathrm{mg}, 60 \%$ of BODIPY $6 \mathbf{6}$ as a dark blue solid: $\mathrm{mp} 233-235{ }^{\circ} \mathrm{C} ;{ }^{1} \mathrm{H}$ NMR $\left(\mathrm{CDCl}_{3}, 500 \mathrm{MHz}\right) \delta(\mathrm{ppm})=8.28-8.29(\mathrm{~m}$, 2H), 7.66-7.69 (m, 6H), 7.51-7.53 (m, 2H), 7.41-7.47 (m, 3H), 6.98-6.99 (m, 4H), $6.82(\mathrm{~s}$, $2 \mathrm{H}), 3.87(\mathrm{~s}, 6 \mathrm{H}) ;{ }^{13} \mathrm{C} \mathrm{NMR}(\mathrm{CDCl} 3,125 \mathrm{MHz}) \delta(\mathrm{ppm})=165.5,161.0,155.2,137.9$, 135.7, 132.6, 132.1, 132.0, 130.4, 129.9, 128.7, 128.5, 128.3, 127.8, 123.2, 121.4, 113.6, $67.2,55.3 ;{ }^{11} \mathrm{~B} \mathrm{NMR}\left(\mathrm{CDCl}_{3}, 128 \mathrm{MHz}\right) \delta(\mathrm{ppm})=0.35-0.82\left(\mathrm{t}, J_{(\mathrm{B}, \mathrm{F})}=30.7 \mathrm{~Hz}\right) ; \mathrm{HRMS}$ (ESI-TOF): $\mathrm{m} / \mathrm{z}$ calcd for $\mathrm{C}_{37} \mathrm{H}_{27} \mathrm{BCl}_{2} \mathrm{~F}_{2} \mathrm{~N}_{2} \mathrm{O}_{4}$ : 681.1451; found: 681.1450 [ $\mathrm{M}^{-}$].

1.1.5. 8-(4-Cyanophenyl)-3,5-di(4-methoxyphenyl)-2,6-dichloro-BODIPY (6b): This BODIPY was prepared from (5b) $(8.5 \mathrm{mg}, 0.02 \mathrm{mmol})$ and 10 eq of 4-methoxyphenyl boronic acid (30.0 mg, $0.2 \mathrm{mmol}$ ), yielding $7.5 \mathrm{mg}, 66 \%$ of BODIPY $\mathbf{6 b}$ as dark blue solid: $\mathrm{mp} 288-290{ }^{\circ} \mathrm{C} ;{ }^{1} \mathrm{H} \mathrm{NMR}\left(\mathrm{CDCl}_{3}, 500 \mathrm{MHz}\right) \delta(\mathrm{ppm})=7.87-7.89(\mathrm{~d}, J=7.7 \mathrm{~Hz}, 2 \mathrm{H})$, 7.66-7.71 (m, 6H), 6.97-6.98 (d, $J=8.2 \mathrm{~Hz}, 4 \mathrm{H}), 6.76(\mathrm{~s}, 2 \mathrm{H}), 3.86(\mathrm{~s}, 6 \mathrm{H}) ;{ }^{13} \mathrm{C}$ NMR $\left(\mathrm{CDCl}_{3}, 125 \mathrm{MHz}\right) \delta(\mathrm{ppm})=161.1,155.7,139.6,138.0,132.3,132.0,131.0,128.0,127.5$, 123.6, 121.2, 117.8, 114.5, 113.6, 55.3; ${ }^{11} \mathrm{~B} \mathrm{NMR}\left(\mathrm{CDCl}_{3}, 128 \mathrm{MHz}\right) \delta(\mathrm{ppm})=0.35-0.82$ (t, $J_{(\mathrm{B}, \mathrm{F})}=30.6 \mathrm{~Hz}$ ); HRMS (ESI-TOF): $\mathrm{m} / \mathrm{z}$ calcd for $\mathrm{C}_{30} \mathrm{H}_{20} \mathrm{BCl}_{2} \mathrm{~F}_{2} \mathrm{~N}_{3} \mathrm{O}_{2}: 572.1035$; found: $572.1026\left[\mathrm{M}^{-}\right]$.

1.1.6. 8-(4-Cyanophenyl)-3,5-di(4-methoxyphenyl)-2-(4-methoxyphenyl)-6-(4cyanophenyl)-BODIPY (8): This BODIPY was prepared from (6b) (8.1 mg, $0.0141 \mathrm{mmol})$, 5 eq of 4-methoxyphenyl boronic acid $(10.7 \mathrm{mg}, 0.0707 \mathrm{mmol})$. The crude product then reacted with 5 eq of 4-cyanophenyl boronic acid $(10.4 \mathrm{mg}, 0.0707 \mathrm{mmol})$, yielding $5.4 \mathrm{mg}$, $54 \%$ of BODIPY 8 as dark blue solid: $\mathrm{mp}\left(273-275{ }^{\circ} \mathrm{C}\right) ;{ }^{1} \mathrm{H} \mathrm{NMR}\left(\mathrm{CDCl}_{3}, 500 \mathrm{MHz}\right) \delta$ $(\mathrm{ppm})=7.90-7.88(\mathrm{~m}, 2 \mathrm{H}), 7.78-7.80(\mathrm{~m}, 2 \mathrm{H}), 7.44-7.47(\mathrm{~m}, 4 \mathrm{H}), 7.38-7.40(\mathrm{~m}, 2 \mathrm{H})$, 7.12-7.10 (M, 2H), 6.93-6.95 (M, 2H), 6.83-6.89 (m, 6H), 6.73-6.75 (m, 2H), 3.84 (s, 3H), $3.83(\mathrm{~s}, 3 \mathrm{H}), 3.77(\mathrm{~s}, 3 \mathrm{H}) ;{ }^{13} \mathrm{C} \mathrm{NMR}(\mathrm{CDCl} 3,125 \mathrm{MHz}) \delta(\mathrm{ppm})=160.8,160.5,160.0$, 159.1, 155.2, 139.4, 138.9, 138.8, 136.5, 134.9, 133.7, 132.3, 132.1, 132.0, 131.9, 131.1, 129.6, 128.7, 128.1, 126.6, 125.7, 123.4, 123.3, 118.9, 118.0, 114.2, 113.8, 113.8, 113.6, $110.2,55.3,55.2 ;{ }^{11} \mathrm{~B} \mathrm{NMR}\left(\mathrm{CDCl}_{3}, 128 \mathrm{MHz}\right) \delta(\mathrm{ppm})=0.68-1.15\left(\mathrm{t}, J_{(\mathrm{B}, \mathrm{F})}=30.5 \mathrm{~Hz}\right)$; HRMS (ESI-TOF): $\mathrm{m} / z$ calcd for $\mathrm{C}_{44} \mathrm{H}_{31} \mathrm{BF}_{2} \mathrm{~N}_{4} \mathrm{O}_{3}: 711.2499$; found: 711.2482 [M $]$.

\subsection{General procedure for Stille cross-couplings reactions-The starting} BODIPY was added to a $15 \mathrm{~mL}$ round-bottomed flask followed by the organotin reagent, $3 \% \mathrm{~mol}$ of $\mathrm{Pd}\left(\mathrm{PPh}_{3}\right)_{4}$ (for 2 ) or $\mathrm{Pd}\left(\mathrm{PCy}_{3}\right) \mathrm{G} 2$ (for 3, 4, 7). The flask was evacuated and refilled with nitrogen three times. Toluene $(5 \mathrm{~mL})$ was added, and the reaction mixture was stirred and heated at $90-100{ }^{\circ} \mathrm{C}$ under nitrogen. Analytical TLC was used to monitor the reaction every 30-60 min. After completion, toluene was removed under vacuum, and the 
resulting residue was purified by column chromatography using dichloromethane/hexanes or ethyl acetate/hexanes as the elution solvents.

1.2.1. 3,5,8-Triphenyl-2,6-dichloro-BODIPY (2): This BODIPY was prepared from (1) $(10.5 \mathrm{mg}, 0.0288 \mathrm{mmol})$ and 10 eq of tributylphenylstannane $(106 \mathrm{mg}, 0.288 \mathrm{mmol})$, yielding $8.6 \mathrm{mg}, 61 \%$ of BODIPY (2) as a purple solid: $\mathrm{mp} 215-217{ }^{\circ} \mathrm{C} ;{ }^{1} \mathrm{H} \mathrm{NMR}\left(\mathrm{CDCl}_{3}\right.$, $400 \mathrm{MHz}) \delta(\mathrm{ppm})=7.58-7.68(\mathrm{~m}, 9 \mathrm{H}), 7.44-7.45(\mathrm{~m}, 6 \mathrm{H}), 6.91(\mathrm{~s}, 2 \mathrm{H}) ;{ }^{13} \mathrm{C} \mathrm{NMR}$ $\left(\mathrm{CDCl}_{3}, 125 \mathrm{MHz}\right) \delta(\mathrm{ppm})=155.0,144.6,133.4,133.0,130.9,130.4,130.2,130.2,130.0$, $129.2,128.7,128.4,127.9,123.0,122.9 ;{ }^{11} \mathrm{~B} \mathrm{NMR}\left(\mathrm{CDCl}_{3}, 128 \mathrm{MHz}\right) \delta(\mathrm{ppm})=0.27-0.74$ (t, $J_{(\mathrm{B}, \mathrm{F})}=29.9 \mathrm{~Hz}$ ); HRMS (ESI-TOF): $\mathrm{m} / z$ calcd for $\mathrm{C}_{27} \mathrm{H}_{17} \mathrm{BCl}_{2} \mathrm{~F}_{2} \mathrm{~N}_{2}: 487.0872$; found: $487.0868\left[\mathrm{M}^{-}\right]$.

1.2.2. 3,5,8-Triphenyl-2,6-dithienyl-BODIPY (3): This BODIPY was prepared from (2) (12.4 mg, $0.0254 \mathrm{mmol}$ ) and 10 eq of 2-(tributylstannyl)thiophene (94.6 mg, $0.254 \mathrm{mmol}$ ), yielding $9.2 \mathrm{mg}, 62 \%$ of BODIPY (3) as a dark blue solid: $\mathrm{mp} 178-180{ }^{\circ} \mathrm{C} ;{ }^{1} \mathrm{H}$ NMR $\left(\mathrm{CDCl}_{3}, 500 \mathrm{MHz}\right) \delta(\mathrm{ppm})=7.72-7.70(\mathrm{~m}, 2 \mathrm{H}), 7.68-7.62(\mathrm{~m}, 3 \mathrm{H}), 7.54-7.53(\mathrm{~m}, 4 \mathrm{H})$, 7.46-7.39 (m, 6H), 7.10-7.09 (dd, $J=5.1,1.1 \mathrm{~Hz}, 2 \mathrm{H}), 7.01(\mathrm{~s}, 2 \mathrm{H}), 6.84-6.82$ (dd, $J=5.1$, $3.6 \mathrm{~Hz}, 2 \mathrm{H}), 6.56-6.55(\mathrm{dd}, J=3.7,1.1 \mathrm{~Hz}, 2 \mathrm{H}) ;{ }^{13} \mathrm{C} \mathrm{NMR}\left(\mathrm{CDCl}_{3}, 125 \mathrm{MHz}\right) \delta(\mathrm{ppm})=$ 156.2, 144.27, 135.8, 134.5, 134.1, 131.4, 130.6, 130.5, 130.2, 129.5, 128.6, 128.1, 128.0, $127.2,126.8,125.1,124.7 ;{ }^{11} \mathrm{~B} \mathrm{NMR}\left(\mathrm{CDCl}_{3}, 128 \mathrm{MHz}\right) \delta(\mathrm{ppm})=0.44-0.90\left(\mathrm{t}, J_{(\mathrm{B}, \mathrm{F})}=\right.$ $29.7 \mathrm{~Hz}$ ); HRMS (ESI-TOF) $\mathrm{m} / \mathrm{z}$ calcd for $\mathrm{C}_{35} \mathrm{H}_{23} \mathrm{BF}_{2} \mathrm{~N}_{2} \mathrm{~S}_{2}$ : 564.1411; found: 564.142 [M$\mathrm{F}]^{+}$.

1.2.3. 2,3,5,6,8-Pentaphenyl-BODIPY (4): This BODIPY was prepared from (2) (13.0 mg, $0.0266 \mathrm{mmol}$ ) and $10 \mathrm{eq}$ of tributylphenylstannane $(97.6 \mathrm{mg}, 0.266 \mathrm{mmol})$, yielding $6.2 \mathrm{mg}$, $41 \%$ of BODIPY (4) as a dark blue solid: mp $273-275{ }^{\circ} \mathrm{C} .{ }^{1} \mathrm{H}$ NMR $\left(\mathrm{CDCl}_{3}, 400 \mathrm{MHz}\right) \delta$ $(\mathrm{ppm})=7.71-7.73(\mathrm{~m}, 2 \mathrm{H}), 7.58-7.66(\mathrm{~m}, 3 \mathrm{H}), 7.50-7.52(\mathrm{~m}, 4 \mathrm{H}), 7.32-7.39(\mathrm{~m}, 6 \mathrm{H})$, 7.17-7.19 (m, 6H), $7.03(\mathrm{~s}, 6 \mathrm{H}) ;{ }^{13} \mathrm{C} \mathrm{NMR}\left(\mathrm{CDCl}_{3}, 125 \mathrm{MHz}\right) \delta(\mathrm{ppm})=156.5,143.9$, 134.7, 134.4, 133.9, 131.8, 130.7, 130.4, 130.3, 129.1, 128.6, 128.4, 128.3, 128.2, 127.9, $126.9 ;{ }^{11} \mathrm{~B}$ NMR $\left(\mathrm{CDCl}_{3}, 128 \mathrm{MHz}\right) \delta(\mathrm{ppm})=0.69-1.16\left(\mathrm{t}, J_{(\mathrm{B}, \mathrm{F})}=30.4 \mathrm{~Hz}\right) ; \mathrm{HRMS}$ (ESI-TOF): $\mathrm{m} / \mathrm{z}$ calcd for $\mathrm{C}_{39} \mathrm{H}_{27} \mathrm{BF}_{2} \mathrm{~N}_{2} \mathrm{Na}$ : 594.2164; found: 594.2147 [M+Na] ${ }^{+}$.

1.2.4. 8-(4-Cyanophenyl)-3,5-di(4-methoxyphenyl)-2,6-dithienyl-BODIPY (7): This BODIPY was prepared from $(\mathbf{6 b})(9.6 \mathrm{mg}, 0.0167 \mathrm{mmol})$ and 10 eq of 2(tributylstannyl)thiophene (62.4 $\mathrm{mg}, 0.167 \mathrm{mmol}$ ), yielding $6.2 \mathrm{mg}, 55 \%$ of BODIPY 7 as a dark blue solid: $\mathrm{mp} 268-270{ }^{\circ} \mathrm{C} ;{ }^{1} \mathrm{H}$ NMR $\left(\mathrm{CDCl}_{3}, 500 \mathrm{MHz}\right) \delta(\mathrm{ppm})=7.93(\mathrm{~m}, 2 \mathrm{H}), 7.81$ (m, 2H), 7.49-7.48 (m, 4H), $7.14(\mathrm{dd}, J=5.1,1.1 \mathrm{~Hz}, 2 \mathrm{H}), 6.94(\mathrm{~m}, 4 \mathrm{H}), 6.87$ (dd, $J=5.1$, $3.6 \mathrm{~Hz}, 2 \mathrm{H}), 6.84(\mathrm{~s}, 2 \mathrm{H}), 6.62(\mathrm{dd}, J=3.7,1.2 \mathrm{~Hz}, 2 \mathrm{H}), 3.86(\mathrm{~s}, 6 \mathrm{H}) ;{ }^{13} \mathrm{C} \mathrm{NMR}\left(\mathrm{CDCl}_{3}\right.$, $125 \mathrm{MHz}) \delta(\mathrm{ppm})=160.7,157.2,139.8,138.7,135.5,134.0,132.3,131.8,131.1,128.7$, 127.3, 125.9, 125.4, 125.0, 123.2, 118.1, 114.2, 113.6, 55.2; ${ }^{11} \mathrm{~B}$ NMR $\left(\mathrm{CDCl}_{3}, 128 \mathrm{MHz}\right) \delta$ $(\mathrm{ppm})=0.47-0.94\left(\mathrm{t}, J_{(\mathrm{B}, \mathrm{F})}=29.8 \mathrm{~Hz}\right) ; \mathrm{HRMS}(\mathrm{ESI}-\mathrm{TOF}): \mathrm{m} / \mathrm{z}$ calcd for $\mathrm{C}_{38} \mathrm{H}_{26} \mathrm{BFN}_{3} \mathrm{O}_{2} \mathrm{~S}_{2}: 649.1574$; found: $649.1546[\mathrm{M}-\mathrm{F}]^{+}$. 


\section{Crystallography}

Crystal structures were determined using data collected at $\mathrm{T}=90 \mathrm{~K}$ on a diffractometer.

MoKa radiation was used for $\mathbf{2}, \mathbf{4}, \mathbf{5 a}, \mathbf{6 a}$, and $\mathbf{6 b}$, while $\mathrm{CuKa}$ was used for $\mathbf{7}$ and $\mathbf{8}$.

Compound 5a exhibited a small amount (ca. 10\%) of rotational disorder which was evident from partially-populated secondary sites for all the $\mathrm{Cl}$ atoms. Compound $\mathbf{6 a}$ was a twin and has two molecules in the asymmetric unit. Compound $\mathbf{7}$ had both thiophenes disordered into two orientations, with relative occupations 70:30 and 80:20. It also had disordered solvent, which was removed using the SQUEEZE procedure. Compound $\mathbf{8}$ had one methoxy group disordered into 54:46 orientations and also had disordered solvent removed by SQUEEZE. Crystal Data: 2, $\mathrm{C}_{27} \mathrm{H}_{17} \mathrm{BCl}_{2} \mathrm{~F}_{2} \mathrm{~N}_{2}$, monoclinic, $a=15.5375(10), b=6.0426(4), c=$ 23.7983(16) $\AA, \beta=93.080(3)^{\circ}$, space group $P 2_{1} / \mathrm{c}, Z=4,48,015$ reflections measured, $\theta_{\max }$ $=36.5^{\circ}, 10,891$ unique $\left(R_{\text {int }}=0.052\right)$, final $\mathrm{R}=0.041(8237 \mathrm{I}>2 \sigma(\mathrm{I})$ data $), \mathrm{w} R\left(F^{2}\right)=0.109$ (all data), $\mathrm{CCDC} 1509815 ; 4, \mathrm{C}_{39} \mathrm{H}_{27} \mathrm{BF}_{2} \mathrm{~N}_{2}$, monoclinic, $a=27.801(3), b=8.5828(11), c=$ 25.471(4) $\AA, \beta=105.021(10)^{\circ}$, space group $C 2 / \mathrm{c}, Z=8,16,414$ reflections measured, $\theta_{\max }$ $=23.3^{\circ}, 4177$ unique $\left(R_{\mathrm{int}}=0.115\right)$, final $\mathrm{R}=0.077(2159 \mathrm{I}>2 \sigma(\mathrm{I})$ data $), \mathrm{w} R\left(F^{2}\right)=0.218$ (all data), CCDC 1509816; 5a, $\mathrm{C}_{23} \mathrm{H}_{13} \mathrm{BCl}_{4} \mathrm{~F}_{2} \mathrm{~N}_{2} \mathrm{O}_{2}$, monoclinic, $a=13.7912(4), b=$ 10.6546(4), $c=15.2354(6) \AA, \beta=99.863(2)^{\circ}$, space group $P 2_{1} / \mathrm{n}, Z=4,24,073$ reflections measured, $\theta_{\max }=31.0^{\circ}, 7034$ unique $\left(R_{\text {int }}=0.035\right)$, final $\mathrm{R}=0.045$ (5519 $\mathrm{I}>2 \sigma(\mathrm{I})$ data), $\mathrm{w} R\left(F^{2}\right)=0.130$ (all data), CCDC $1509817 ; \mathbf{6 a}, \mathrm{C}_{37} \mathrm{H}_{27} \mathrm{BCl}_{2} \mathrm{~F}_{2} \mathrm{~N}_{2} \mathrm{O}_{4}$, triclinic, $a=$ 13.0943(15), $b=13.8006(16), c=17.659(2) \AA, a=83.546(7), \beta=83.396(7), \gamma=$ $80.198(7)^{\circ}$, space group $P-1, Z=4,27,197$ reflections measured, $\theta_{\max }=24.0^{\circ}, 16,564$ unique $\left(R_{\text {int }}=0.119\right)$, final $\mathrm{R}=0.093\left(8684 \mathrm{I}>2 \sigma(\mathrm{I})\right.$ data), $\mathrm{w} R\left(F^{2}\right)=0.264$ (all data), CCDC 1509818; $6 \mathbf{b}, \mathrm{C}_{30} \mathrm{H}_{20} \mathrm{BCl}_{2} \mathrm{~F}_{2} \mathrm{~N}_{3} \mathrm{O}_{2}$, triclinic, $a=6.4378(3), b=13.1056(7), c=15.3828(8)$ $\AA$ A $\alpha=84.902(2), \beta=79.560(2), \gamma=84.620(2)^{\circ}$, space group $P-1, Z=2,14,444$ reflections measured, $\theta_{\max }=28.3^{\circ}, 5922$ unique $\left(R_{\mathrm{int}}=0.030\right)$, final $\mathrm{R}=0.038$ (4794 $\mathrm{I}>2 \sigma(\mathrm{I})$ data), $\mathrm{w} R\left(F^{2}\right)=0.092$ (all data), CCDC 1509819; 7, $\mathrm{C}_{38} \mathrm{H}_{26} \mathrm{BF}_{2} \mathrm{~N}_{3} \mathrm{O}_{2} \mathrm{~S}_{2}$, triclinic, $a=9.8322(8), b$ $=13.3203(11), c=15.0587(12) \AA, a=72.208(6), \beta=74.473(6), \gamma=81.456(6)^{\circ}$, space group $P-1, Z=2,19,146$ reflections measured, $\theta_{\max }=62.8^{\circ}, 5632$ unique $\left(R_{\mathrm{int}}=0.074\right)$, final $\mathrm{R}=0.062$ (3310 I $>2 \sigma(\mathrm{I})$ data), $\mathrm{w} R\left(F^{2}\right)=0.170$ (all data), CCDC 1509820; 8 , $\mathrm{C}_{44} \mathrm{H}_{31} \mathrm{BF}_{2} \mathrm{~N}_{4} \mathrm{O}_{3}$. $\mathrm{CHCl}_{3}$, triclinic, $a=10.3829(9), b=14.3659(14), c=15.0975(14) \AA, a=$ 75.674(7), $\beta=89.346(7), \gamma=78.359(7)^{\circ}$, space group $P-1, Z=2,19,963$ reflections measured, $\theta_{\max }=68.4^{\circ}, 7279$ unique $\left(R_{\mathrm{int}}=0.061\right)$, final $\mathrm{R}=0.105$ (5062 I $>2 \sigma(\mathrm{I})$ data $)$, $\mathrm{w} R\left(F^{2}\right)=0.341$ (all data), CCDC 1509821 .

\section{Spectroscopic Studies}

All UV-visible and fluorescence spectra were collected on a UV spectrometer and a luminescence spectrometer at $298 \mathrm{~K}$, respectively. A $10 \mathrm{~mm}$ path length quartz cuvette and spectroscopic solvents were used for all the measurements. Molar absorption coefficients ( $\varepsilon$ ) were determined from the slope of absorbance $v s$ concentration of five dilute solutions with absorbance in the range of $0.2-1.0$. Fluorescence quantum yields $\left(\Phi_{\mathrm{f}}\right)$ were determined by using a series of dilute solutions with absorbance in the range of 0.02-0.06 at a particular excitation wavelength. Cresyl violet perchlorate ( 0.55 in methanol) and methylene blue (0.03 in methanol) were used as external standards for BODIPYs $2, \mathbf{6 a}, \mathbf{6 b}, \mathbf{4}$ and $\mathbf{3}, \mathbf{7}, \mathbf{8}$, 
respectively. The relative fluorescence quantum yields $\left(\Phi_{\mathrm{f}}\right)$ were determined using the following equation (1), ${ }^{4 \mathrm{c}}$

$$
\phi_{x}=\phi_{R}\left[\frac{\operatorname{Grad}_{X}}{\operatorname{Grad}_{R}}\right]\left[\frac{\eta_{X}^{2}}{\eta_{R}^{2}}\right]
$$

where $\Phi$ represent the fluorescence quantum yields; $\eta$ represent the refractive indexes of solvents; Grad represent the gradient from the plot of integrated fluorescence intensity $v s$ absorbance at $\lambda_{\text {ex }}$; Subscripts $\mathrm{X}$ and $\mathrm{R}$ represent the tested sample and standard sample respectively.

\section{DFT Calculations}

The DFT calculations were carried out using the Gaussian 09 software package. The ground state geometries of the BODIPYs were optimized by the DFT method with the B3LYP functional and 6-31G(d) basis sets. ${ }^{29}$

\section{Cyclic voltammetry}

Cyclic voltammetry was carried out using a potentiostat coupled to an Universal

Programmer. Current-voltage curves were recorded on an X-Y recorder. A homemade threeelectrode cell was used for cyclic voltammetric measurements and consisted of a glassy carbon working electrode, a platinum counter electrode and a homemade saturated calomel reference electrode (SCE). The SCE was separated from the bulk of the solution by a fritted bridge of low porosity, which contained the solvent/supporting electrolyte mixture.

Benzonitrile ( $\mathrm{PhCN}$, reagentPlus, 99\%) for electrochemistry was freshly distilled over $\mathrm{P}_{2} \mathrm{O}_{5}$ before use.

\section{Cell studies}

The cell studies were conducted by adapting reported procedures. ${ }^{28 \mathrm{~b}}$ All cell culture media and reagents were used as received. The human HEp2 cells were maintained in a 50:50 mixture of DMEM:AMEM supplemented with 5\% FBS and 1\% penicillin/streptomycin antibiotic. The cells were sub-cultured twice weekly to maintain sub-confluent stocks.

6.1. Dark Cytotoxicity-The HEp2 cells were plated at 7500 cells per well in a 96 -well plate and allowed to grow for $48 \mathrm{~h}$. Stock solutions of the BODIPYs (32 mM) were prepared in $100 \%$ DMSO and diluted into final working concentrations $(0,6.25,12.5,25,50,100 \mu \mathrm{M}$ and $200 \mu \mathrm{M}$ ). The cells were exposed to the working solutions of compounds up to $200 \mu \mathrm{M}$ and incubated overnight $\left(37^{\circ} \mathrm{C}, 95 \%\right.$ humidity, $\left.5 \% \mathrm{CO}_{2}\right)$. The working solution was removed, and the cells were washed with $1 \mathrm{X}$ PBS. The medium containing $20 \%$ CellTiter Blue was added and incubated for $4 \mathrm{~h}$. The viability of cells is measured by reading the fluorescence of the medium at 570/615 nm using a micro-plate reader. In this assay, the indicator dye resazurin is reduced to fluorescent resorufin in viable cells, while non-viable cells are not able to reduce resazurin nor to generate a fluorescent signal. The fluorescence signal of viable (untreated) cells was normalized to $100 \%$ and non-viable (treated with $0.2 \%$ saponin) cells was normalized to $0 \%$. 
6.2. Phototoxicity-The human HEp2 cells were prepared as described above and incubated with compound concentrations of $100,50,25,12.5,6.25,3.125$, and $0 \mu \mathrm{M}$ for 24 $\mathrm{h}$. The loading solution was removed and the cells were washed with $1 \times \mathrm{PBS}$, and then refilled with fresh medium. The cells were exposed to a $600 \mathrm{~W}$ halogen lamp light source filtered with a water filter (transmits radiation $250-950 \mathrm{~nm}$ ) and a beam turning mirror with $200 \mathrm{~nm}$ to $30 \mu \mathrm{m}$ spectral range, for $20 \mathrm{~min}$. The total light dose provided was approximately $1.5 \mathrm{~J} / \mathrm{cm}^{2}$. After light exposure, the cells were stored in the incubator for $24 \mathrm{~h}$ and assayed for cell viability as described above.

6.3. Time-Dependent Cellular Uptake-Human HEp2 cells were prepared as described above. The cells were exposed to $10 \mu \mathrm{M}$ of each compound solution for $0,1,2,4,8$, and 24

$\mathrm{h}$. The loading medium was removed at the end of each incubation period and the cells were washed with $1 \mathrm{X}$ PBS, and solubilized by adding $0.25 \%$ Triton X-100 in 1X PBS. Each compound solution was diluted to $10,5,2.5,1.25,0.625$ and $0.3125 \mu \mathrm{M}$ concentrations using $0.25 \%$ Triton X-100 in $1 \mathrm{X}$ PBS for standard curve. A cell standard curve was prepared using $10^{4}, 2 \times 10^{4}, 4 \times 10^{4}, 6 \times 10^{4}, 8 \times 10^{4}$, and $10^{5}$ cells per well. The cell number was quantified using a CyQuant Cell Proliferation Assay. The compound concentration in cells at each time period was determined using a micro-plate reader at $485 / 590 \mathrm{~nm}$. Cellular uptake is expressed in terms of compound concentration (nM) per cell.

6.4. Microscopy-Human HEp2 cells were cultured in a 6-well plate and allowed to grow in the incubator $\left(37^{\circ} \mathrm{C}, 95 \%\right.$ humidity, $\left.5 \% \mathrm{CO}_{2}\right)$ for $24 \mathrm{~h}$. The cells were exposed to10 $\mu \mathrm{M}$ of each BODIPY in medium and incubated for $6 \mathrm{~h}\left(37^{\circ} \mathrm{C}, 95 \%\right.$ humidity, $\left.5 \% \mathrm{CO}_{2}\right)$, followed by the addition of organelle tracers ( $50 \mathrm{nM}$ LysoSensor Green, $250 \mathrm{nM}$ MitoTracker Green, $100 \mathrm{nM}$ ER Tracker Blue/White and $50 \mathrm{nM}$ BODIPY FL C5 Ceramide) and incubated for $30 \mathrm{~min}$. The cells were washed with PBS three times before imaging. The images were obtained by an upright microscopy with a water immersion objective and DAPI, GFP, and Texas Red filter cubes.

\section{Supplementary Material}

Refer to Web version on PubMed Central for supplementary material.

\section{Acknowledgments}

This work was supported by grants from the NIH (R01 CA179902), the NSF (CHE 1362641) and the Robert A. Welch Foundation (K. M. K., Grant E-680).

\section{References}

1. Li J, Liu D, Hong Z, Tong S, Wang P, Ma C, Lengyel O, Lee CS, Kwong HL, Lee S. Chem Mater. 2003; 15:1486-1490.

2. (a) Pawlicki M, Collins HA, Denning RG, Anderson HL. Angew Chem Int Ed. 2009; 48:32443266.(b) Reinhardt BA, Brott LL, Clarson SJ, Dillard AG, Bhatt JC, Kannan R, Yuan L, He GS, Prasad PN. Chem Mater. 1998; 10:1863-1874.

3. (a) Ren X, Jiang S, Cha M, Zhou G, Wang ZS. Chem Mater. 2012; 24:3493-3499.(b) Higashino T, Imahori H. Dalton Trans. 2015; 44:448-463. [PubMed: 25381701] (c) Hagfeldt A, Boschloo G, Sun L, Kloo L, Pettersson H. Chem Rev. 2010; 110:6595-6663. [PubMed: 20831177] 
4. (a) Trukhina O, Rudolf M, Bottari G, Akasaka T, Echegoyen L, Torres T, Guldi DM. J Am Chem Soc. 2015; 137:12914-12922. [PubMed: 26401549] (b) Chou HH, Reddy KSK, Wu HP, Guo BC, Lee HW, Diau EWG, Hsu CP, Yeh CY. ACS Appl Mater Interfaces. 2016; 8:3418-3427. [PubMed: 26752243] (c) Jinadasa RGW, Fang Y, Kumar S, Osinski AJ, Jiang X, Ziegler CJ, Kadish KM, Wang H. J Org Chem. 2015

5. (a) Loudet A, Burgess K. Chem Rev. 2007; 107:4891-4932. [PubMed: 17924696] (b) Boens N, Leen V, Dehaen W. Chem Soc Rev. 2012; 41:1130-1172. [PubMed: 21796324] (c) Bessette A, Hanan GS. Chem Soc Rev. 2014; 43:3342-3405. [PubMed: 24577078]

6. (a) Kaur N, Kaur P, Singh K. Sensors Actuators B: Chem. 2016; 229:499-505.(b) Flores-Rizo JO, Esnal I, Osorio-Martínez CA, Gómez-Durán CFA, Bañuelos J, López Arbeloa I, Pannell KH, MettaMagaña AJ, Peña-Cabrera E. J Org Chem. 2013; 78:5867-5877. [PubMed: 23721096] (c) Zhao Y, Lv X, Liu Y, Liu J, Zhang Y, Shi H, Guo W. J Mater Chem. 2012; 22:11475-11478.

7. (a) Kolemen S, Cakmak Y, Erten-Ela S, Altay Y, Brendel J, Thelakkat M, Akkaya EU. Org Lett. 2010; 12:3812-3815. [PubMed: 20704314] (b) Erten-Ela S, Yilmaz MD, Icli B, Dede Y, Icli S, Akkaya EU. Org Lett. 2008; 10:3299-3302. [PubMed: 18588306] (c) Bonnier C, Machin DD, Abdi O, Koivisto BD. Org Biomol Chem. 2013; 11:3756-3760. [PubMed: 23629157]

8. (a) Wang Y, Chen L, El-Shishtawy RM, Aziz SG, Mullen K. Chem Commun. 2014; 50:1154011542.(b) Jiao L, Wu Y, Wang S, Hu X, Zhang P, Yu C, Cong K, Meng Q, Hao E, Vicente MGH. J Org Chem. 2014; 79:1830-1835. [PubMed: 24476041]

9. (a) Niu S, Ulrich G, Retailleau P, Ziessel R. Tetrahedron Lett. 2011; 52:4848-4853.(b) Shi WJ, Lo PC, Singh A, Ledoux-Rak I, Ng DKP. Tetrahedron. 2012; 68:8712-8718.(c) Ulrich G, Barsella A, Boeglin A, Niu S, Ziessel R. Chemphyschem. 2014; 15:2693-2700. [PubMed: 24954812] (d) Nano A, Ziessel R, Stachelek P, Harriman A. Chem Eur J. 2013; 19:13528-13537. [PubMed: 24038505]

10. Sutter A, Retailleau P, Huang WC, Lin HW, Ziessel R. New J Chem. 2014; 38:1701-1710.

11. Didier P, Ulrich G, Mely Y, Ziessel R. Org Biomol Chem. 2009; 7:3639-3642. [PubMed: 19707663]

12. Lu H, Mack J, Yang Y, Shen Z. Chem Soc Rev. 2014; 43:4778-4823. [PubMed: 24733589]

13. (a) Zhao N, Xuan S, Fronczek FR, Smith KM, Vicente MGH. J Org Chem. 2015; 80:8377-8383. [PubMed: 26186141] (b) Wang H, Vicente MGH, Fronczek FR, Smith KM. Chem Eur J. 2014; 20:5064-5074. [PubMed: 24616111] (c) Zhao N, Vicente MGH, Fronczek FR, Smith KM. Chem Eur J. 2015; 21:6181-6192. [PubMed: 25761150]

14. Priestley ES, De Lucca I, Zhou J, Zhou J, Saiah E, Stanton R, Robinson L, Luettgen JM, Wei A, Wen X, Knabb RM, Wong PC, Wexler RR. Biorg Med Chem Lett. 2013; 23:2432-2435.

15. Ishiyama T, Ishida K, Miyaura N. Tetrahedron. 2001; 57:9813-9816.

16. Wang H, Fronczek FR, Vicente MGH, Smith KM. J Org Chem. 2014; 79:10342-10352. [PubMed: 25268574]

17. Hansch C, Leo A, Taft RW. Chem Rev. 1991; 91:165-195.

18. Zhao N, Xuan S, Byrd B, Fronczek FR, Smith KM, Vicente MGH. Org Biomol Chem. 2016; 14:6184-6188. [PubMed: 27251595]

19. Reichardt C. Chem Rev. 1994; 94:2319-2358.

20. Olmsted J. J Phys Chem. 1979; 83:2581-2584.

21. (a) Chen Y, Zhao J, Guo H, Xie L. J Org Chem. 2012; 77:2192-2206. [PubMed: 22316087] (b) Chen Y, Zhao J, Xie L, Guo H, Li Q. RSC adv. 2012; 2:3942-3953.

22. Reichardt, C., Welton, T. Solvents and Solvent Effects in Organic Chemistry. Wiley-VCH Verlag $\mathrm{GmbH} \& \mathrm{Co} . \mathrm{KGaA} ; 2010$. Solvent Effects on the Absorption Spectra of Organic Compounds; p. 359-424.

23. Qin W, Baruah M, Van der Auweraer M, De Schryver FC, Boens N. J Phys Chem A. 2005; 109:7371-7384. [PubMed: 16834104]

24. (a) Lin SH. J Chem Phys. 1970; 53:3766-3767.(b) Rurack K, Kollmannsberger M, Daub J. Angew Chem Int Ed. 2001; 40:385-387.

25. Umezawa K, Matsui A, Nakamura Y, Citterio D, Suzuki K. Chem Eur J. 2009; 15:1096-1106. [PubMed: 19117043]

26. Nepomnyashchii AB, Bard AJ. Acc Chem Res. 2012; 45:1844-1853. [PubMed: 22515199] 
27. Sharma R, Lakshmi V, Chatterjee T, Ravikanth M. New J Chem. 2016; 40:5855-5860.

28. (a) Uppal T, Hu X, Fronczek FR, Maschek S, Bobadova-Parvanova P, Vicente MGH. Chem Eur J. 2012; 18:3893-3905. [PubMed: 22367756] (b) Xuan S, Zhao N, Zhou Z, Fronczek FR, Vicente MGH. J Med Chem. 2016; 59:2109-2117. [PubMed: 26849474] (c) Gibbs JH, Robins LT, Zhou Z, Bobadova-Parvanova P, Cottam M, McCandless GT, Fronczek FR, Vicente MGH. Biorg Med Chem. 2013; 21:5770-5781.

29. Frisch, MJ., Trucks, GW., Schlegel, HB., Scuseria, GE., Robb, MA., Cheeseman, JR., Scalmani, G., Barone, V., Mennucci, B., Petersson, GA., Nakatsuji, H., Caricato, M., Li, X., Hratchian, HP., Izmaylov, AF., Bloino, J., Zheng, G., Sonnenberg, JL., Hada, M., Ehara, M., Toyota, K., Fukuda, R., Hasegawa, J., Ishida, M., Nakajima, T., Honda, Y., Kitao, O., Nakai, H., Vreven, T., Montgomery, JA., Jr, Peralta, JE., Ogliaro, F., Bearpark, MJ., Heyd, J., Brothers, EN., Kudin, KN., Staroverov, VN., Kobayashi, R., Normand, J., Raghavachari, K., Rendell, AP., Burant, JC., Iyengar, SS., Tomasi, J., Cossi, M., Rega, N., Millam, NJ., Klene, M., Knox, JE., Cross, JB., Bakken, V., Adamo, C., Jaramillo, J., Gomperts, R., Stratmann, RE., Yazyev, O., Austin, AJ., Cammi, R., Pomelli, C., Ochterski, JW., Martin, RL., Morokuma, K., Zakrzewski, VG., Voth, GA., Salvador, P., Dannenberg, JJ., Dapprich, S., Daniels, AD., Farkas, Ö., Foresman, JB., Ortiz, JV., Cioslowski, J., Fox, DJ. Gaussian 09. Gaussian, Inc.; Wallingford, CT, USA: 2009. 

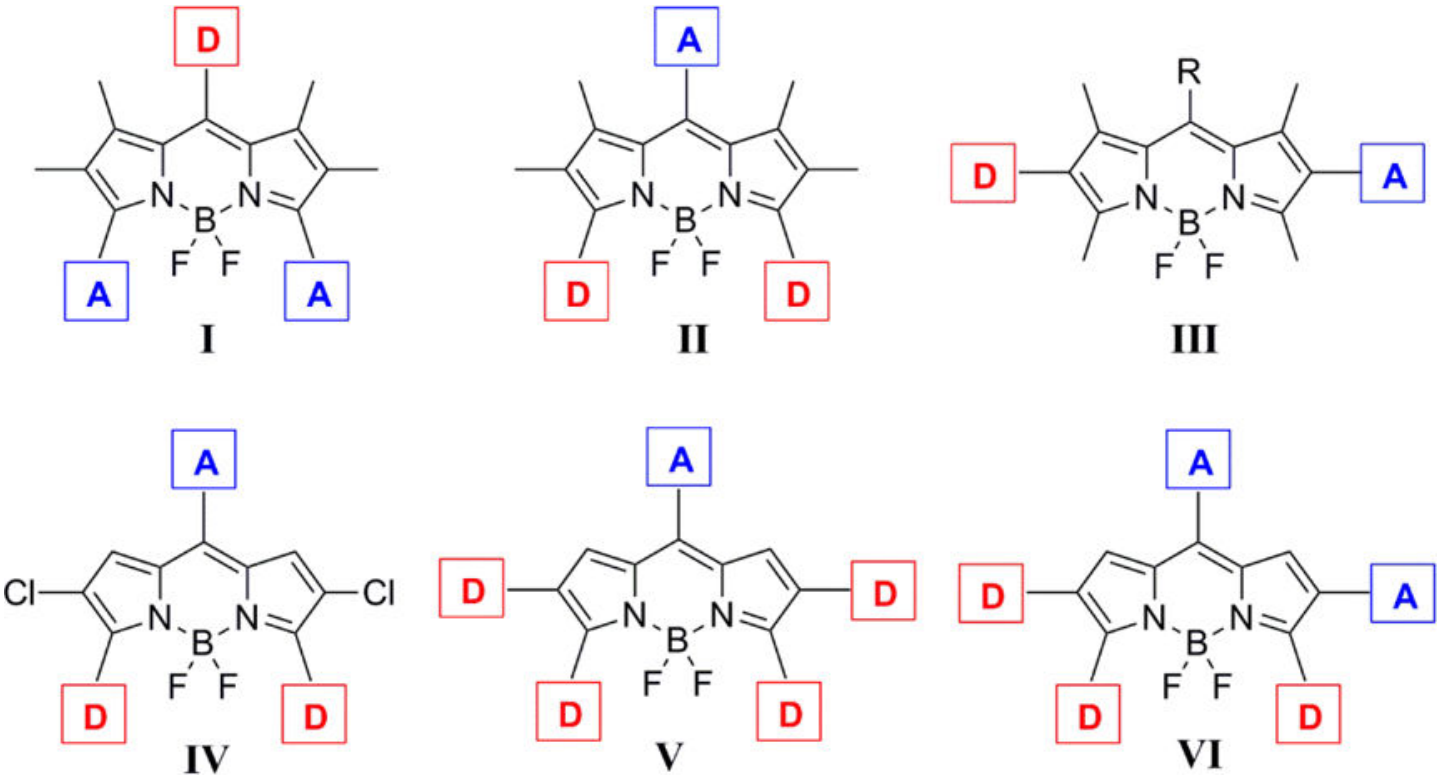

Figure 1.

Platforms of push-pull BODIPYs. D and A represent electron-donor and electron-acceptor groups, respectively (I-III, ref 7c - published by The Royal Society of Chemistry). 


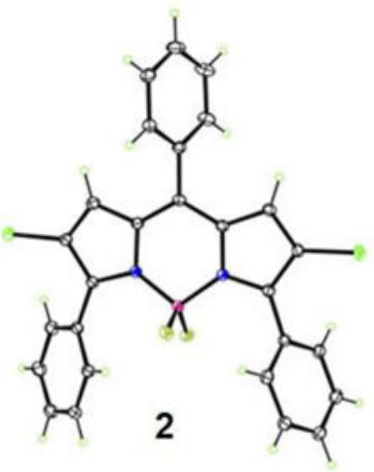

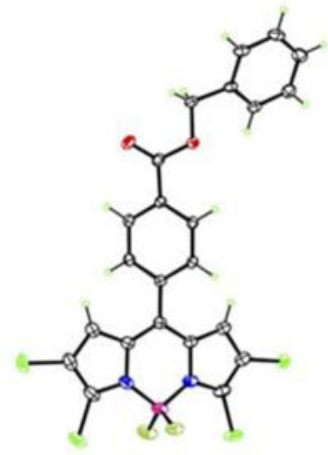

$5 a$
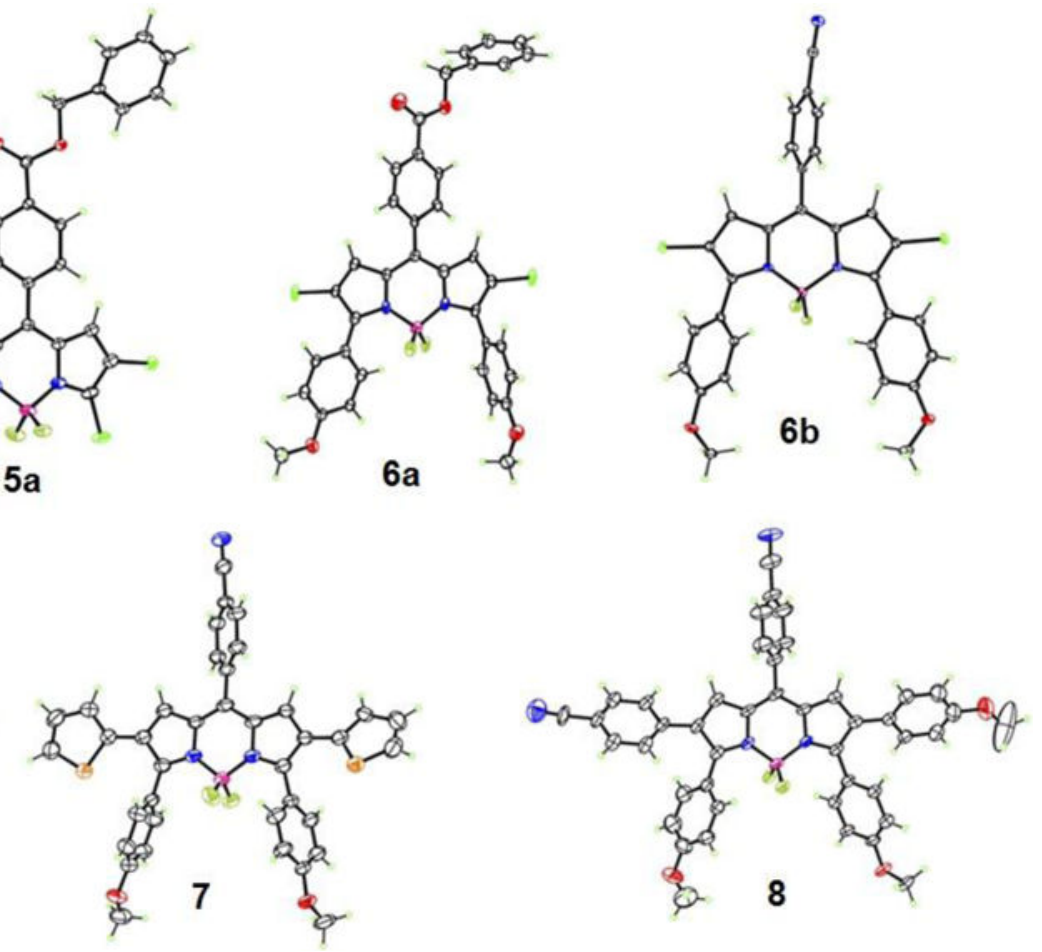

Figure 2.

Crystal structures of BODIPYs $\mathbf{2}, \mathbf{4}, \mathbf{5 a}, \mathbf{6 a}, \mathbf{6 b}, \mathbf{7}$ and $\mathbf{8}$ with $50 \%$ ellipsoids. Only one orientation is shown for disordered regions in $\mathbf{7}$ and $\mathbf{8}$.

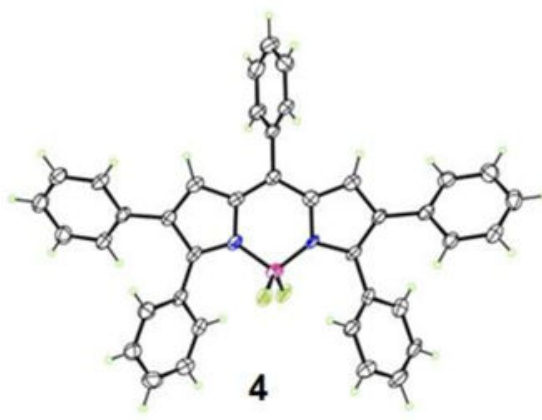

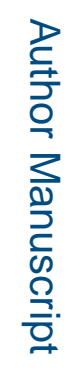



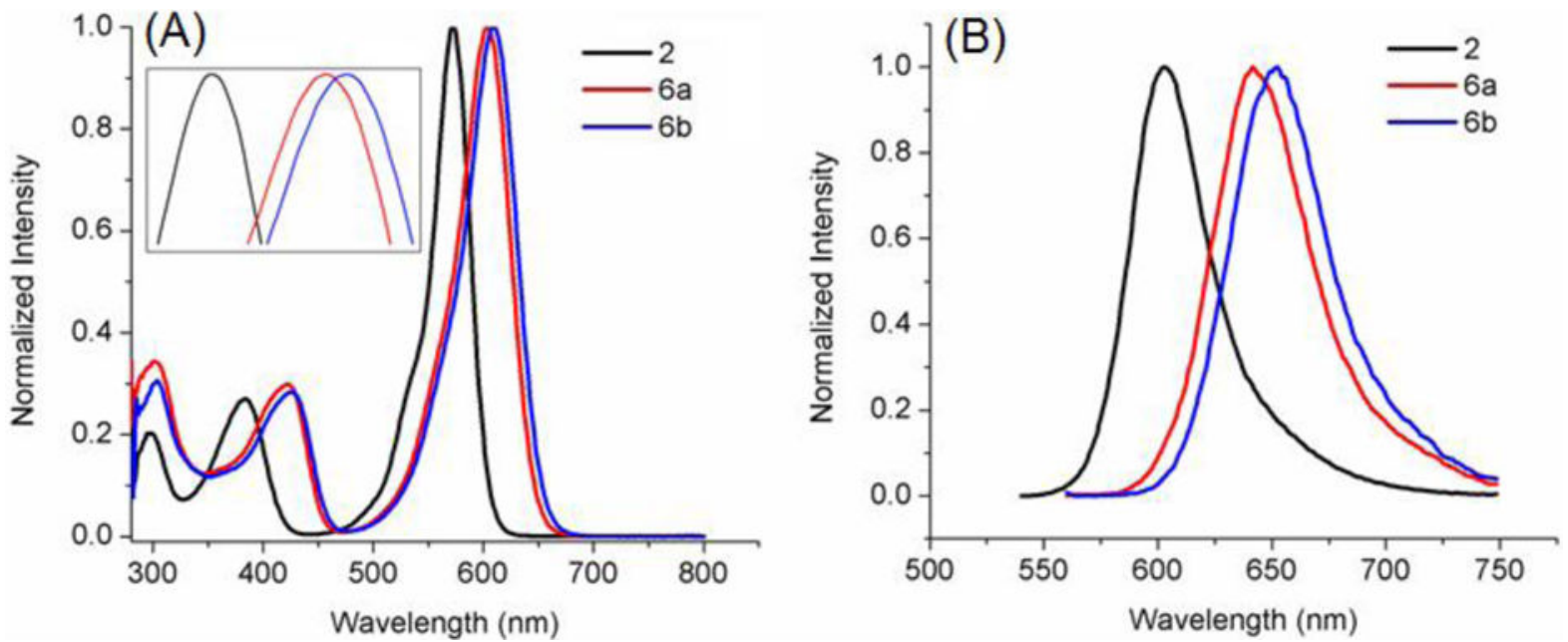

Figure 3.

Absorbance (A) and fluorescence (B) of BODIPYs 2, $6 \mathbf{a}$ and $\mathbf{6 b}$ in toluene. 

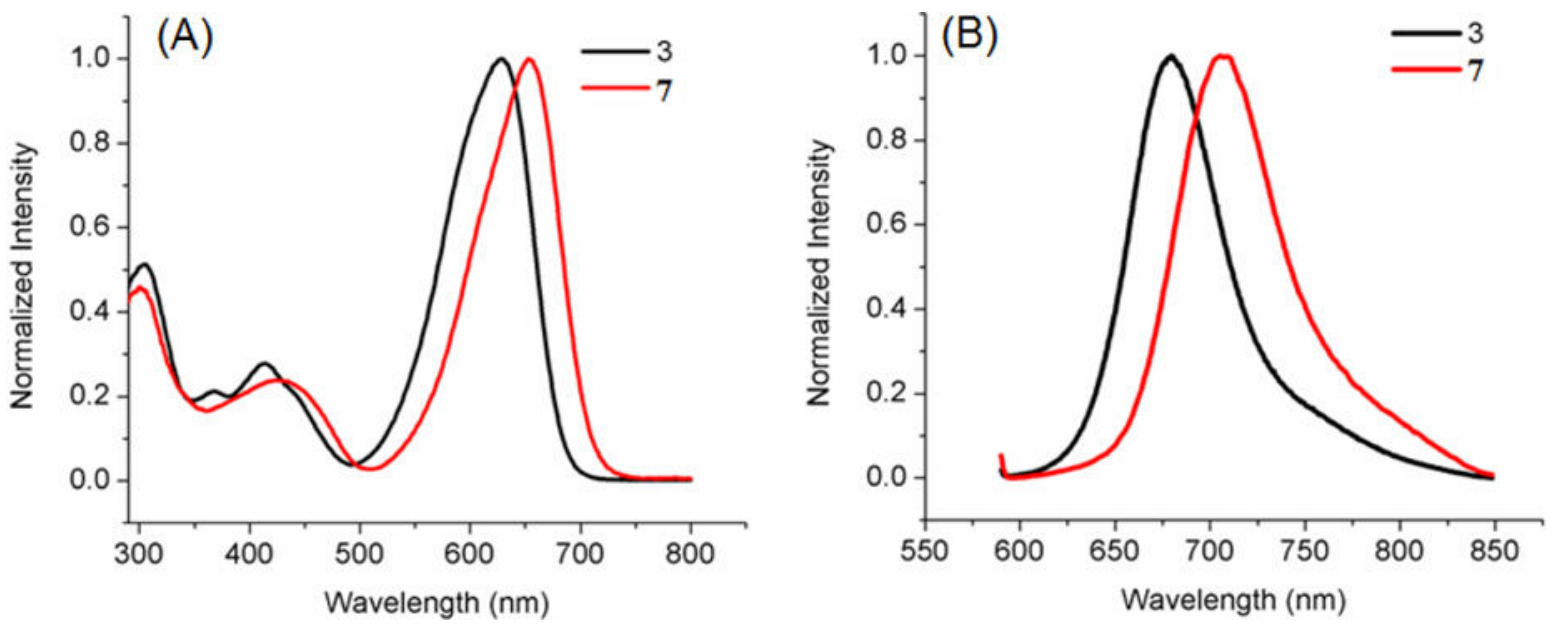

Figure 4.

Absorbance (A) and fluorescence (B) of BODIPYs $\mathbf{3}$ and $\mathbf{7}$ in toluene. 

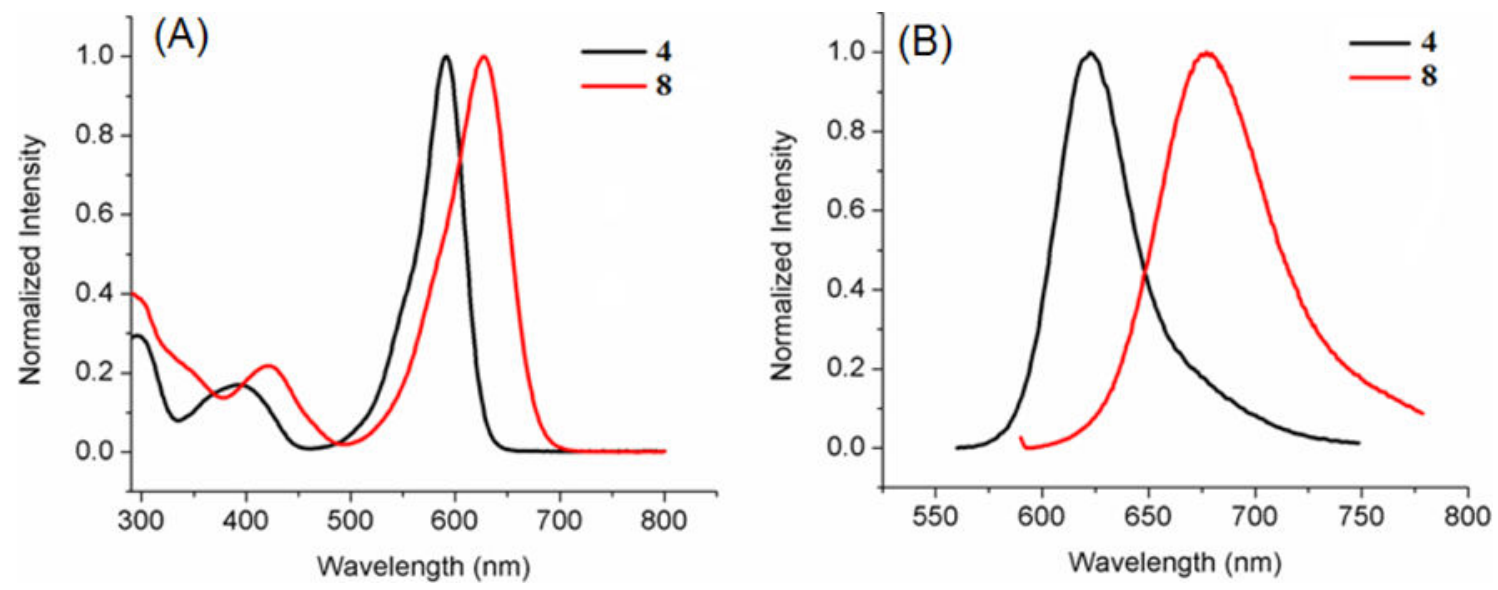

Figure 5.

Absorbance (A) and fluorescence emission (B) of BODIPYs $\mathbf{4}$ and 8 in toluene. 

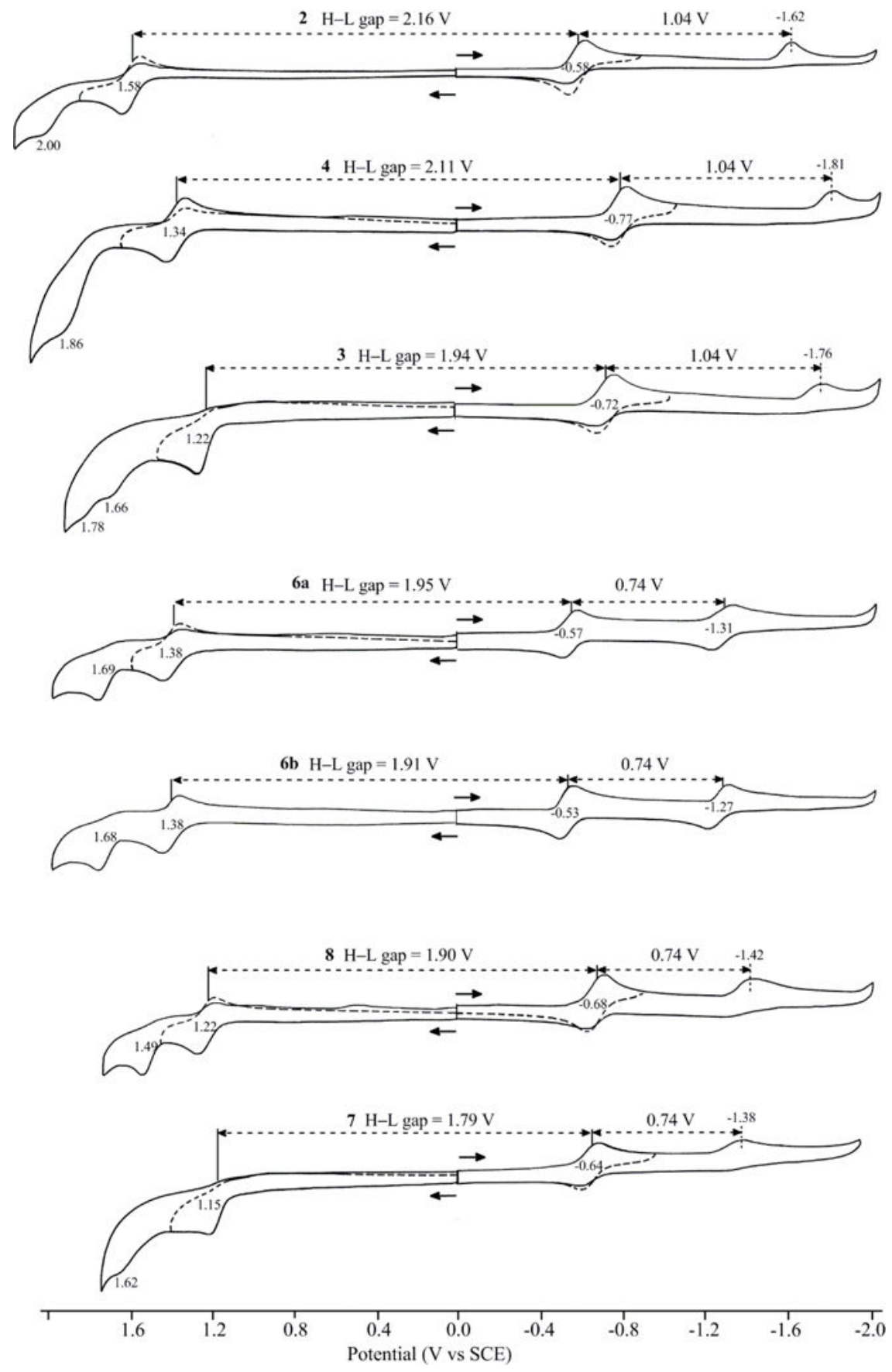

Figure 6.

Cyclic voltammograms for BODIPYs $\mathbf{2}, \mathbf{3}, \mathbf{4}, \mathbf{6 a}, \mathbf{6 b}, \mathbf{7}$ and $\mathbf{8}$ in PhCN with $0.1 \mathrm{M}$ TBAP.

J Org Chem. Author manuscript; available in PMC 2017 July 14. 

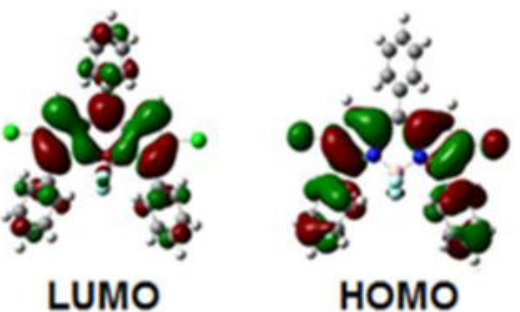

2 LUMO

HOMO

$6 a$
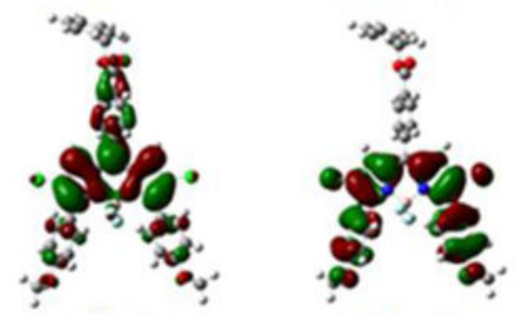

LUMO

HOMO

$6 b$
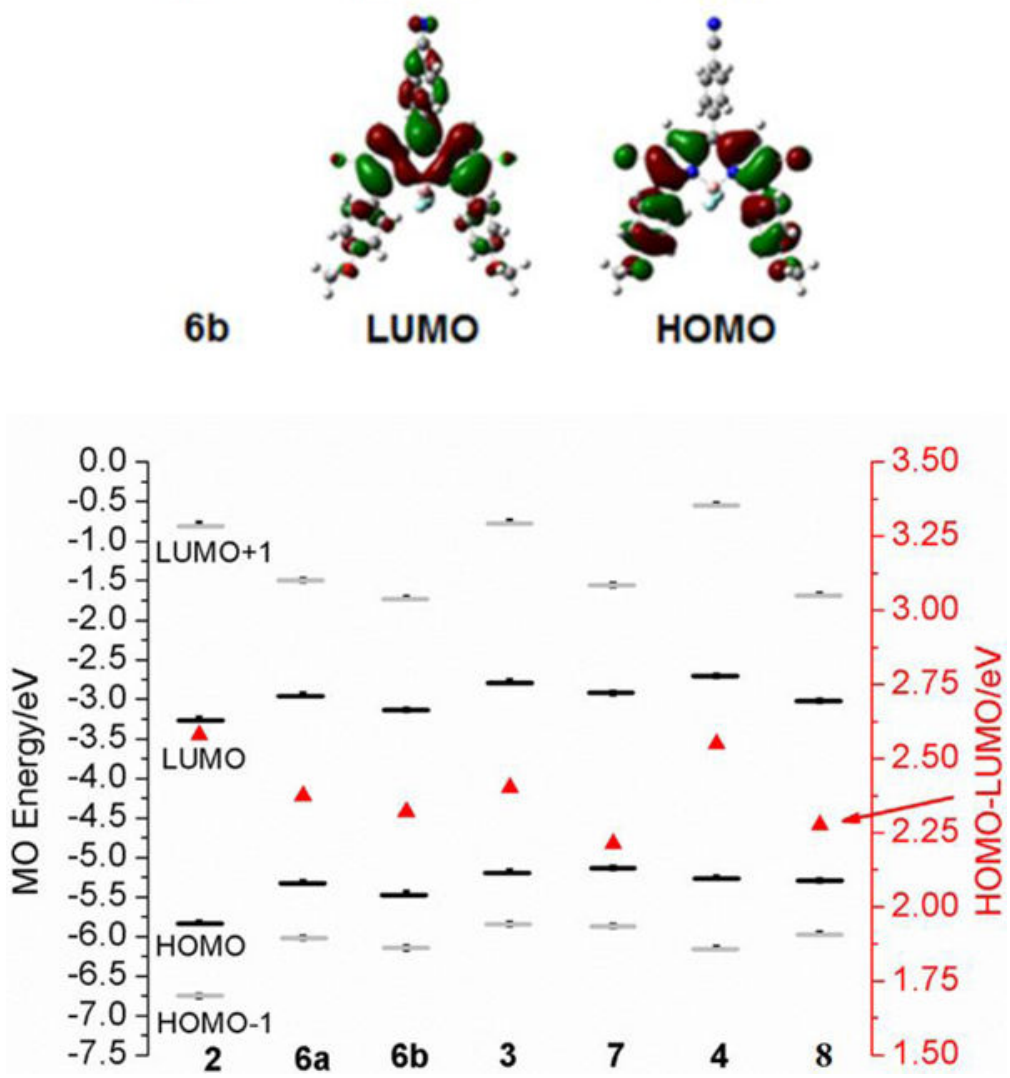

Figure 7.

DFT calculated frontier orbitals for BODIPY 2, 6a and $\mathbf{6 b}$ (upper) and molecular orbital energies for BODIPYs. The HOMO-LUMO gaps are plotted against a secondary axis and are denoted by red triangles (bottom). 


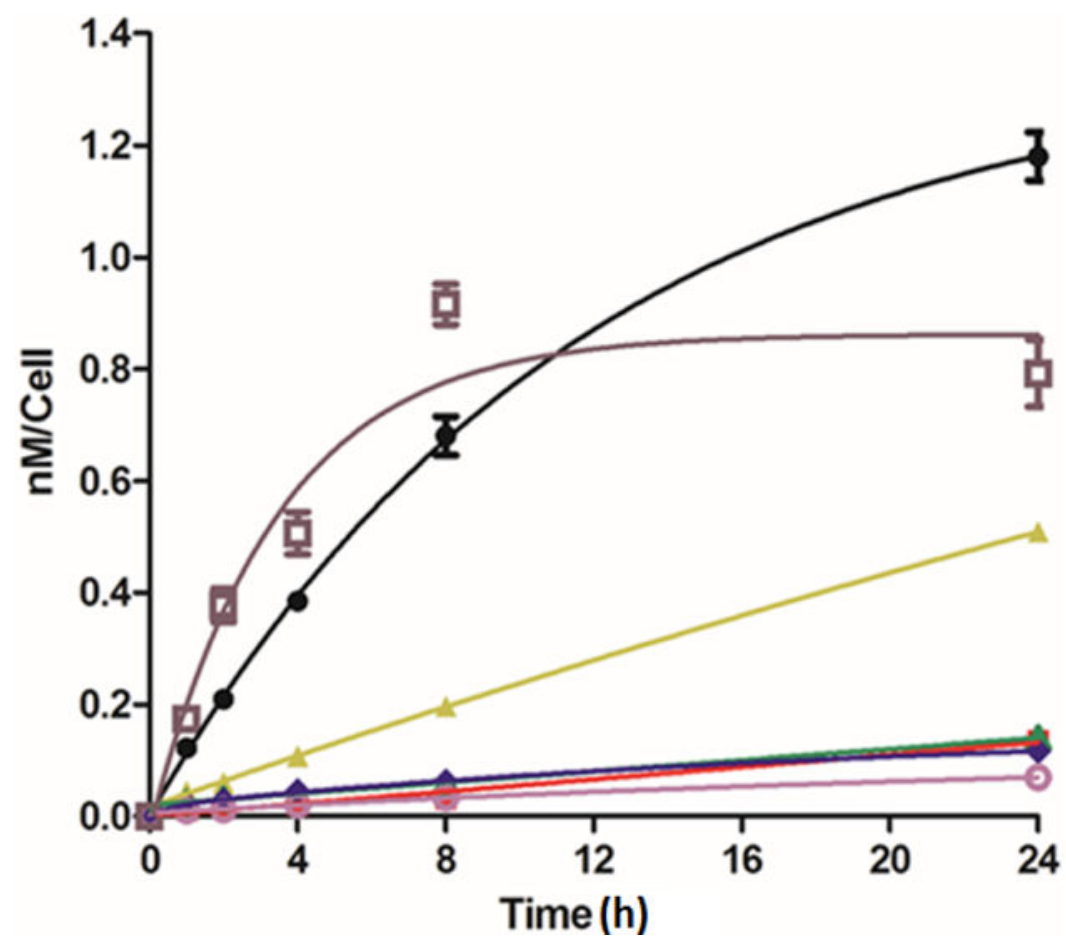

Figure 8.

Time-dependent uptake of BODIPYs 2 (black), $6 \mathbf{a}$ (red), $6 \mathbf{b}$ (yellow), $\mathbf{3}$ (green), 4 (pink), 7 (blue) and $\mathbf{8}$ (brown) in human HEp2 cells at $10 \mu \mathrm{M}$ concentration. 


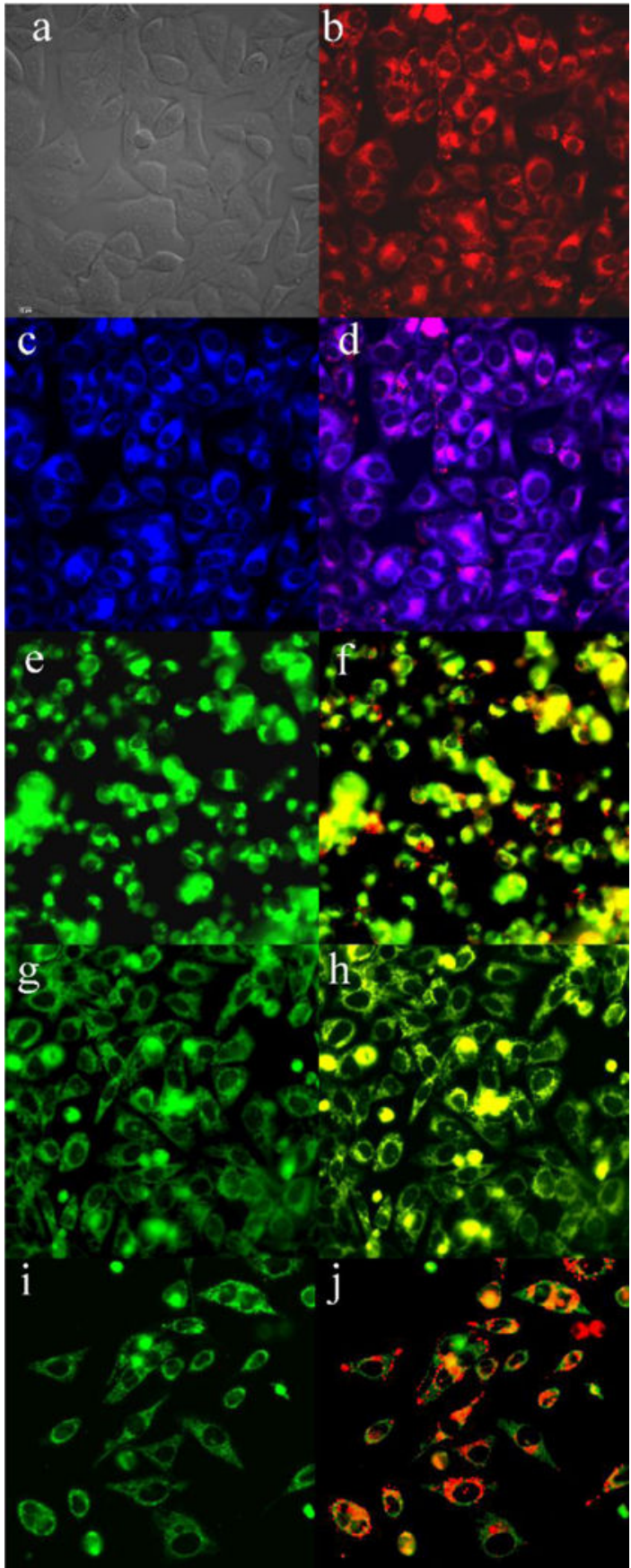

Figure 9.

Subcellular localization of $\mathbf{6 b}$ in HEp2 cells at $10 \mu \mathrm{M}$ for $6 \mathrm{~h}$. (a) phase contrast, (b) overlay of $\mathbf{6 b}$ and phase contrast, (c) ER Tracker Blue/White, (d) overlay of $\mathbf{6 b}$ and ER Tracker, (e) BODIPY Ceramide, (f) overlay of $\mathbf{6 b}$ and BODIPY Ceramide, (g) MitoTracker Green, (h) overlay of $\mathbf{6 b}$ and MitoTracker, (i) LysoSensor Green, (j) overlay of $\mathbf{6 b}$ and LysoSensor Green. Scale bar: $10 \mu \mathrm{m}$. 


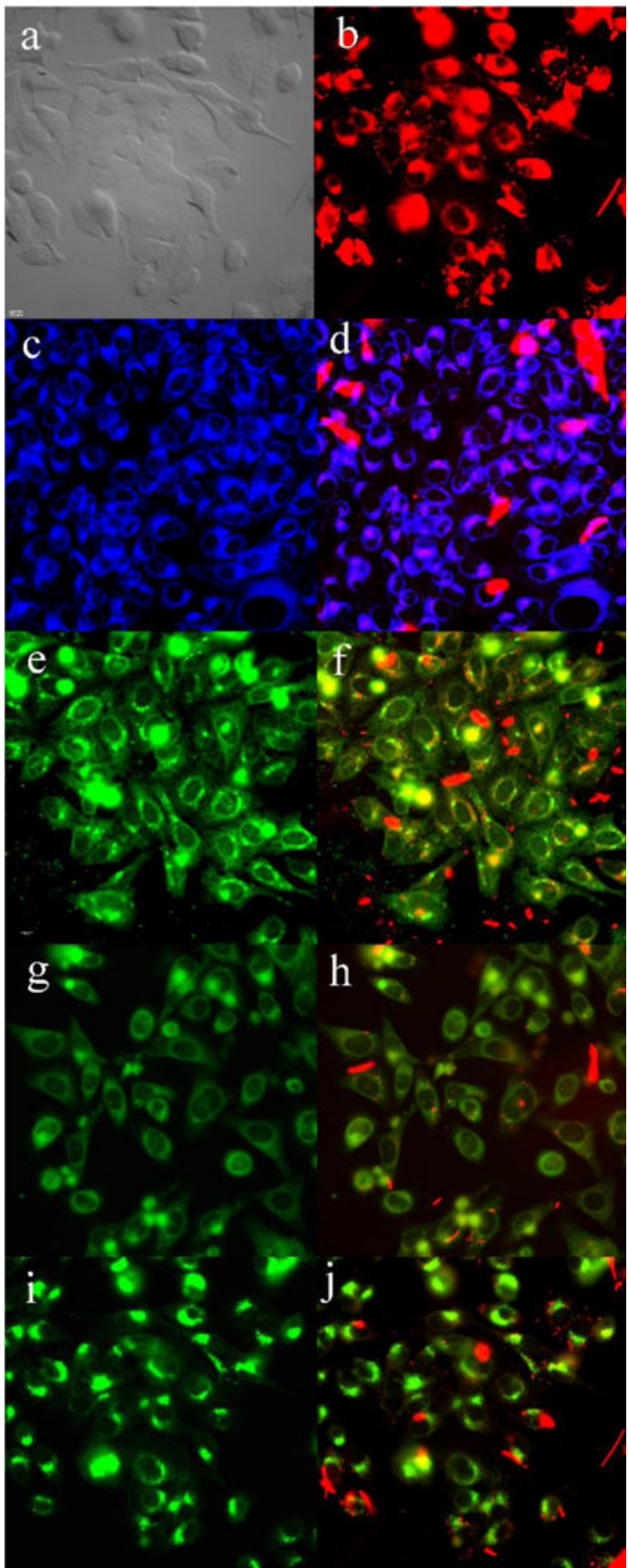

\section{Figure 10.}

Subcellular localization of 8 in HEp2 cells at $10 \mu \mathrm{M}$ for $6 \mathrm{~h}$. (a) phase contrast, (b) overlay of $\mathbf{8}$ and phase contrast, (c) ER Tracker Blue/White, (d) overlay of $\mathbf{8}$ and ER Tracker, (e) BODIPY Ceramide, (f) overlay of $\mathbf{8}$ and BODIPY Ceramide, (g) MitoTracker Green, (h) overlay of $\mathbf{8}$ and MitoTracker, (i) LysoSensor Green, (j) overlay of $\mathbf{8}$ and LysoSensor Green. Scale bar: $10 \mu \mathrm{m}$. 

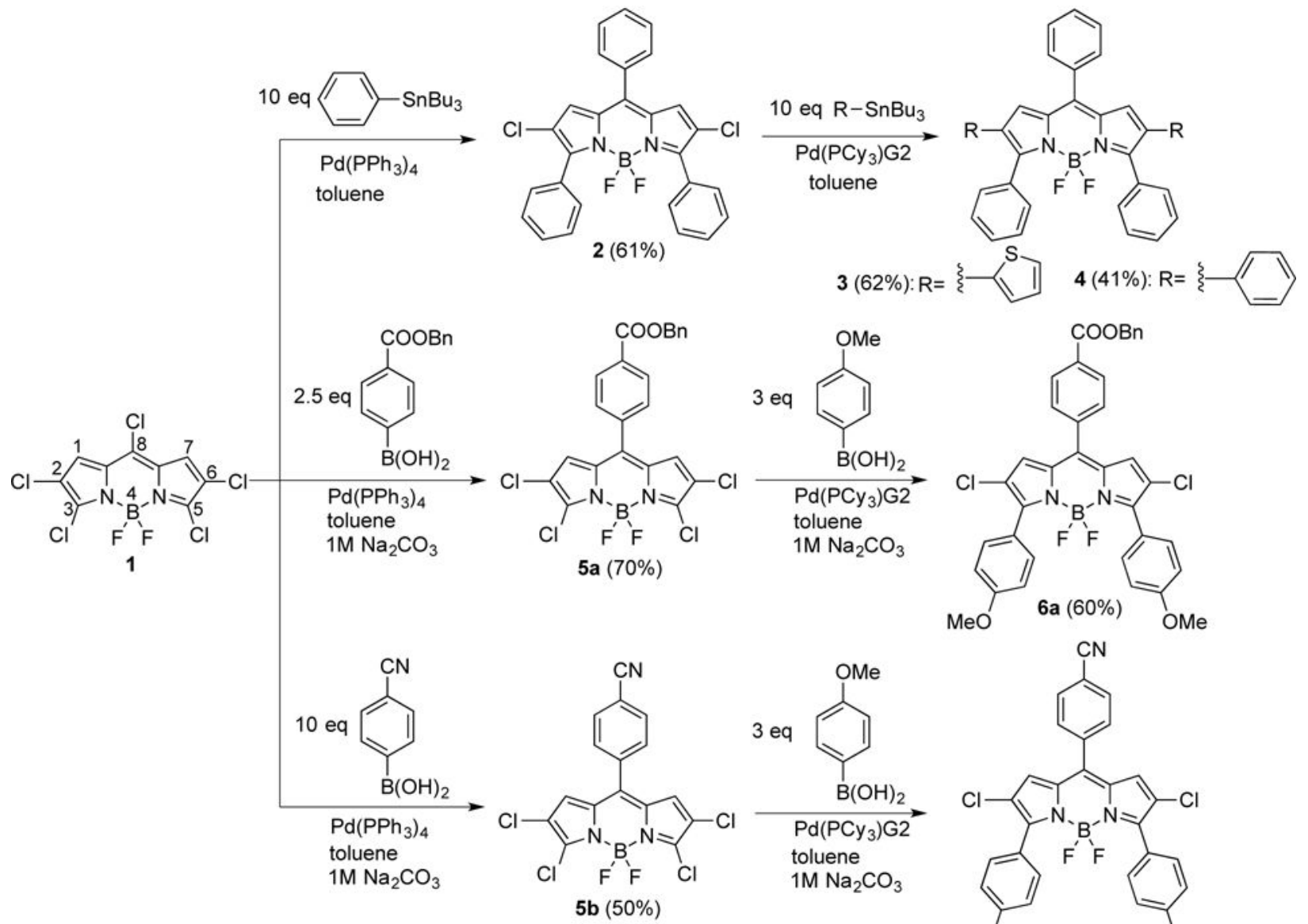

Scheme 1.

Synthetic routes to BODIPYs $\mathbf{2 - 4}, \mathbf{5 a}, \mathbf{5 b}, \mathbf{6 a}$ and $\mathbf{6 b}$. BODIPY numbering system is given in the structure of $\mathbf{1}$. 


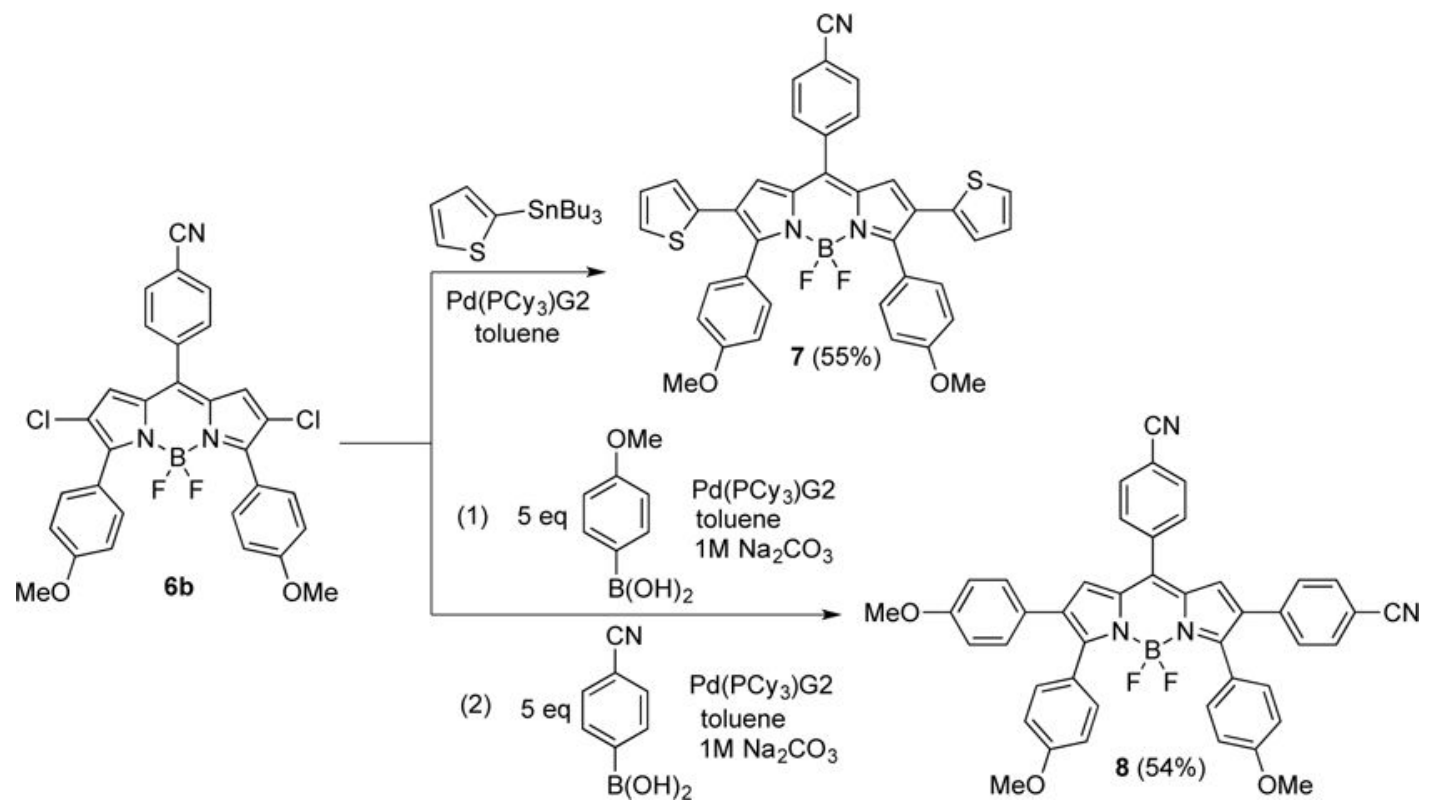

Scheme 2.

Synthetic routes to BODIPYs 7 and $\mathbf{8}$. 


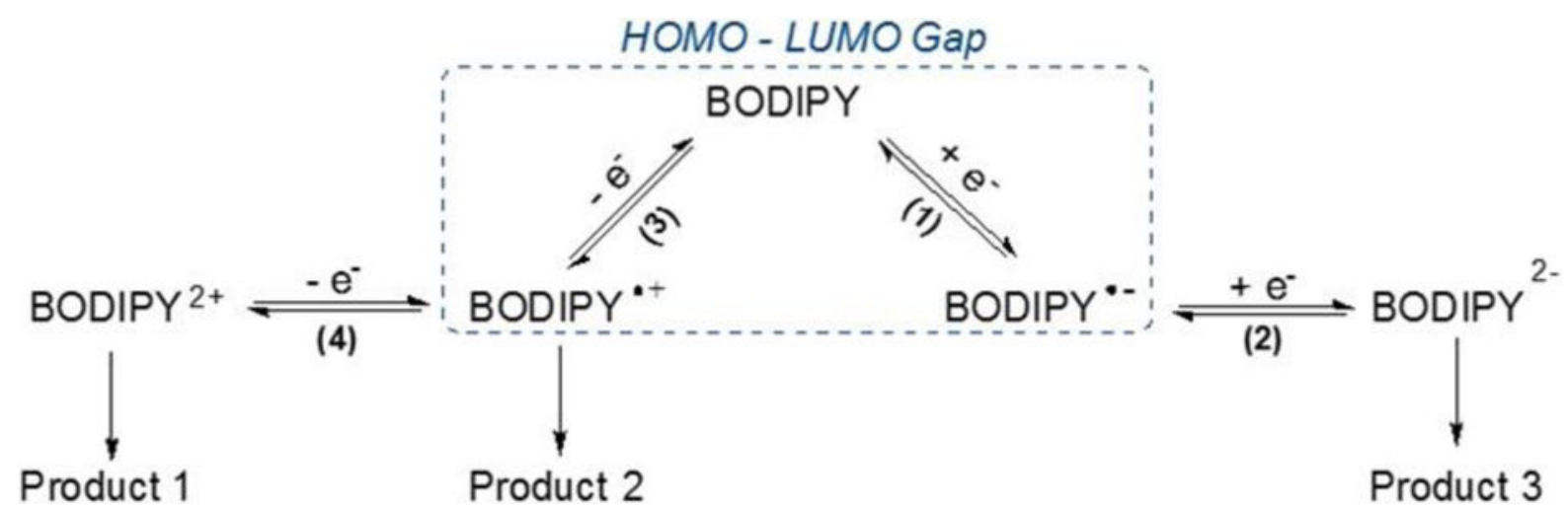

Scheme 3.

Proposed redox reaction mechanisms of BODIPYs. 


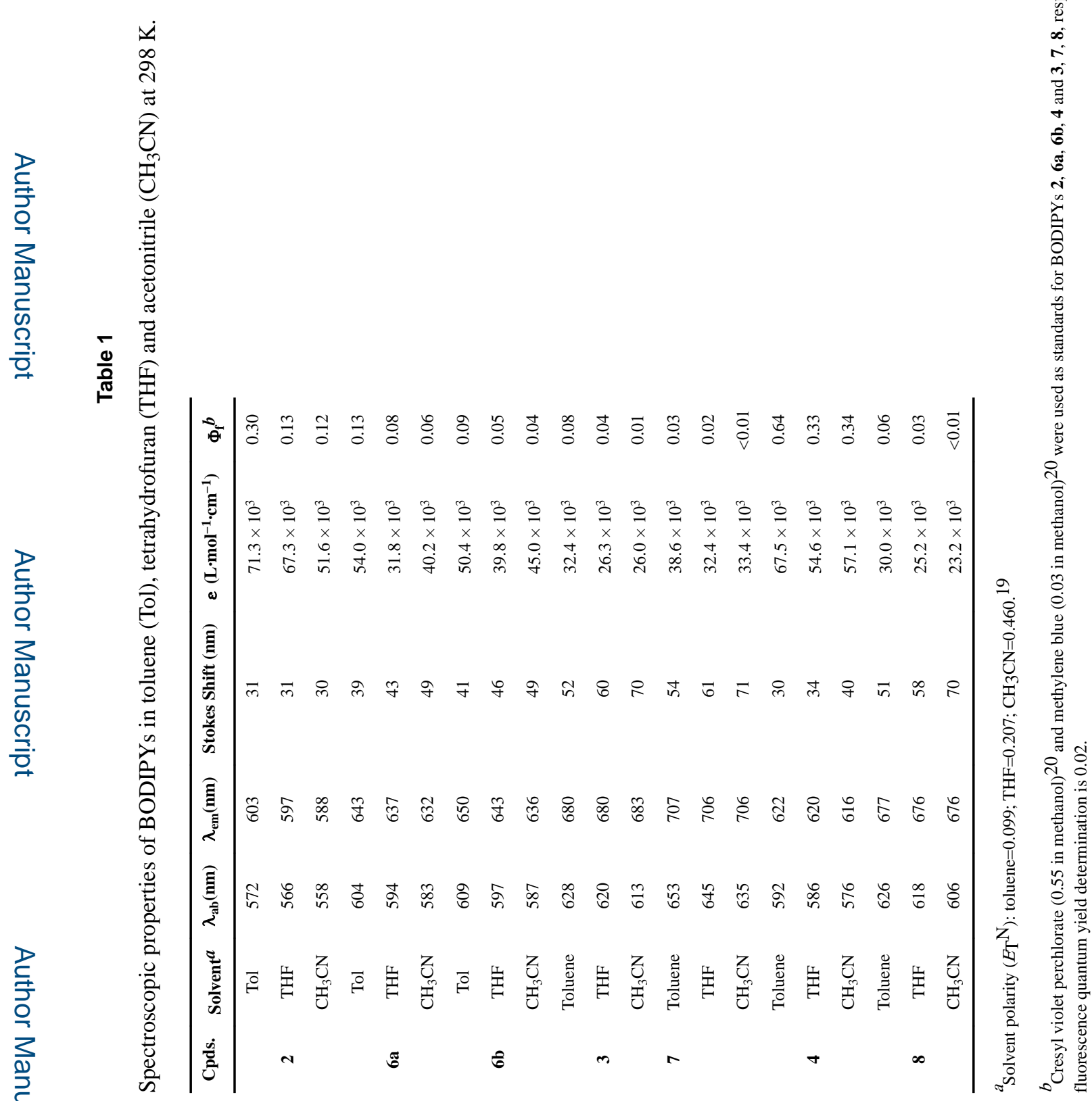




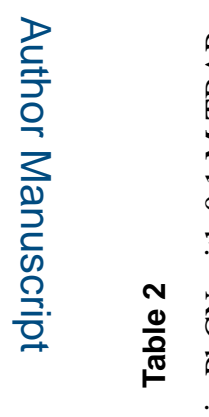

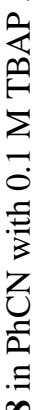

สี

r

ฉ

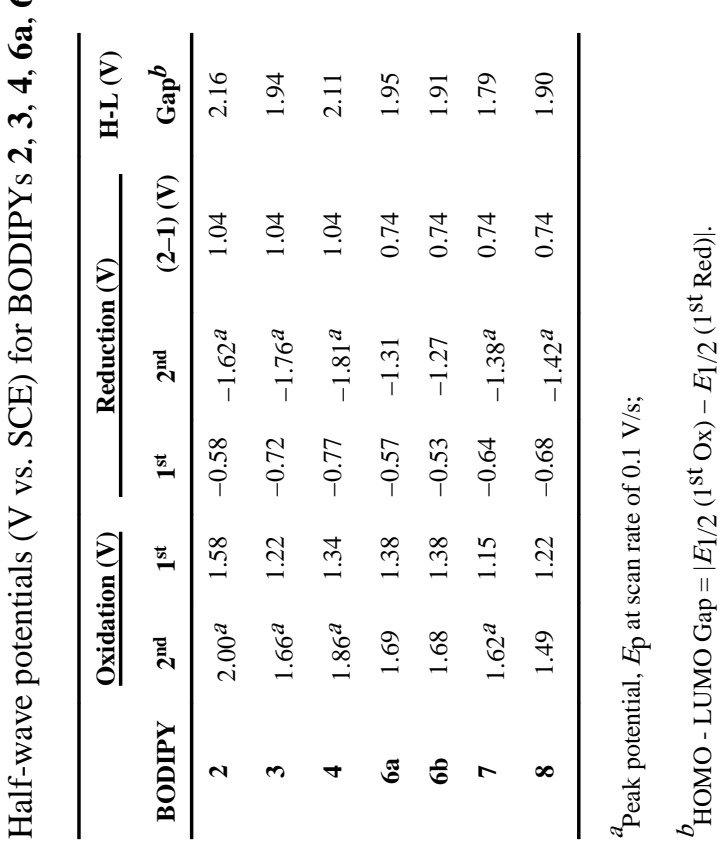

롤

J Org Chem. Author manuscript; available in PMC 2017 July 14. 
Table 3

Dark and phototoxicity and cellular uptake of BODIPYs using human HEp2 cells.

\begin{tabular}{cccc}
\hline Compd. & Dark toxicity $\mathbf{I C}_{\mathbf{5 0}}(\boldsymbol{\mu M})$ & ${\text { Phototoxicity } \mathbf{I C}_{\mathbf{5 0}}(\boldsymbol{\mu M})}$ & Cellular uptake at $\mathbf{2 4} \mathbf{h}(\mathbf{n M} / \mathrm{cell})$ \\
\hline $\mathbf{2}$ & $>200$ & $>100$ & $1.2 \pm 0.10$ \\
$\mathbf{6 a}$ & $>200$ & $>100$ & $0.14 \pm 0.01$ \\
$\mathbf{6 b}$ & $>200$ & $>100$ & $0.51 \pm 0.01$ \\
$\mathbf{3}$ & $>200$ & $>100$ & $0.14 \pm 0.01$ \\
$\mathbf{7}$ & $>200$ & $>100$ & $0.12 \pm 0.01$ \\
$\mathbf{4}$ & $>200$ & $>100$ & $0.058 \pm 0.028$ \\
$\mathbf{8}$ & $>200$ & $>100$ & $0.79 \pm 0.13$ \\
\hline
\end{tabular}

